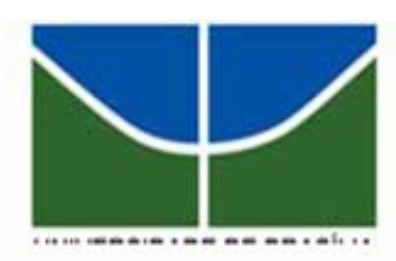

UNIVERSIDADE DE BRASÍLIA Centro de Excelência em Turismo

Pós-graduação Lato Sensu

Curso de Especialização em Turismo e Desenvolvimento Sustentável

\title{
SUSTENTABILIDADE AMBIENTAL NA ATIVIDADE TURÍSTICA: UM OLHAR SOBRE O PROJETO ORLA
}

Josana de Oliveira Lima

Elisângela Machado, Msc, UnB

(Orientadora) 


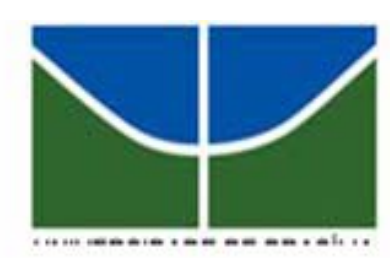

\section{UNIVERSIDADE DE BRASÍLIA Centro de Excelência em Turismo \\ Pós-graduação Lato Sensu}

Curso de Especialização em Turismo e Desenvolvimento

Sustentável

\section{SUSTENTABILIDADE AMBIENTAL NA ATIVIDADE TURÍSTICA: UM OLHAR SOBRE O PROJETO ORLA}

Josana de Oliveira Lima

Elisângela Machado, Msc, UnB

(Orientadora)

Monografia apresentada ao Centro de

Excelência em Turismo - CET, da Universidade de Brasília - UnB, como requisito parcial à obtenção do grau de Especialista em Turismo e Desenvolvimento Sustentável 


\title{
UNIVERSIDADE DE BRASÍLIA Centro de Excelência em Turismo Pós-graduação Lato Sensu \\ Curso de Especialização em Turismo e Desenvolvimento Sustentável
}

\author{
Josana De Oliveira Lima \\ Professora Orientadora: Elisângela Machado, Msc, UnB \\ Professor Examinador: José Aroudo Mota, Dr, UnB \\ Professor Examinador: Umberto Euzébio, Dr, UnB
}


Aos meus pais, José Ferreira Lima e Ana Maria de Oliveira Lima.

Aos meus irmãos e ao meu sobrinho.

Em especial, a Guilherme. 


\section{AGRADECIMENTOS}

A Deus, por ter me dado o dom da vida e a possibilidade de poder realizar meus sonhos.

Aos meus pais, por terem me dado condições e apoio para chegar até aqui.

Aos meus irmãos, pelo auxílio em muitas horas de necessidade e ao meu sobrinho, por alegrar meus dias de trabalho.

Ao Guilherme, meu companheiro em todas as horas, pelo apoio, incentivo e paciência.

A profa Elisângela Machado, pela criteriosa orientação desta pesquisa, apoio e paciência.

Aos professores do Centro de Excelência de Turismo pelos ensinamentos, conhecimento e experiência adquiridos ao longo do curso.

Aos meus companheiros de curso, pois de alguma forma contribuíram para minha formação e enriqueceram minha experiência.

E a todos que de alguma forma auxiliaram na realização deste. 


\section{RESUMO}

É incontestável as inter-relações entre turismo e meio ambiente, já que a atividade turística tem como base e principal insumo o ambiente na qual se localiza. Contudo, esta relação precisa ser constantemente monitorada a fim de evitar que a atividade turística comprometa a sustentabilidade local. A garantia da sustentabilidade advém de um planejamento bem feito e que compreenda os aspectos contemplados pelos princípios do Desenvolvimento Sustentável, como os aspectos econômicos, socioculturais e ambientais. Dentro deste contexto, este trabalho tem como objetivo avaliar a sustentabilidade do Projeto Orla. Este projeto consiste em um plano turístico que busca resgatar o Lago Paranoá para a população de Brasília, tornandoo o principal atrativo da capital federal. Para esta análise foi estabelecida uma metodologia de avaliação de impactos que buscasse contemplar todas as esferas da sustentabilidade. Os resultados mostram que um planejamento, para ser bem feito, precisa ser constantemente revisado e adequado às realidades locais.

Palavras-chaves: turismo, sustentabilidade e Lago Paranoá 


\begin{abstract}
It is incontestable the relations between tourism and environment, and this because the tourist activity has the environment as its basis. The relationship needs to be constantly evaluated in order to avoid that the tourism compromises the local sustainability. The guarantee of the sustainability is acquired through a well done planning that covers all the principles of the Sustainable Development like the economic, social and environmental aspects. In this context, this research has the aim to evaluate the sustainability of the "Projeto Orla". This project is a tourist plan that seeks to rescue the Paranoa Lake for Brasília's people, making it the main tourist point of the Federal District. To make this evaluation, it was established a methodology of impact assessment that covered all the aspects of sustainability. The results show that a plan, to be considered well done, needs to be constantly revised and adequate to the local reality.
\end{abstract}

Keywords: tourism, sustainability and Paranoa Lake. 


\section{LISTA DE ILUSTRAÇÕES}

Figura 1 - Bacias Hidrográficas do Distrito Federal. ........................ 20

Figura 2 - Carta de uso da terra. ............................................... 22

Figura 3 - O Projeto Orla e seus pólos. ........................................ 25

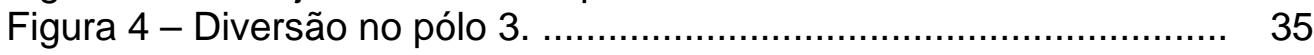

Figura 5 - Substituição da cobertura vegetal no pólo 3. ..................... 39

Figura 6 - Lixo nas margens do lago. ............................................. 41

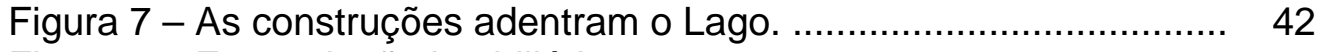

Figura 8 - Especulação imobiliária. ............................................... 43

Figura 9 - Entrada em estilo medieval do Pontão. ............................. 47

Figura 10 - Vegetação na orla do pólo 11. ....................................... 47

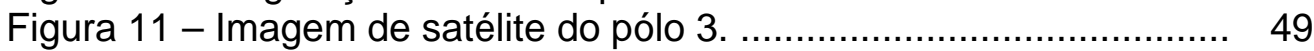

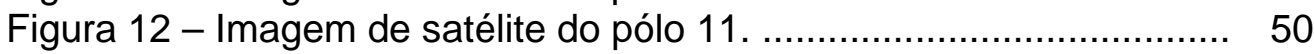




\section{LISTA DE QUADROS}

Quadro 1 - Impactos / Externalidades causados pelo turismo.............. 11

Quadro 2 - Modelo de Matriz de Interação ...................................... 33

Quadro 3 - Matriz de Interação - Complexo do Brasília Palace ............. 36

Quadro 4 - Síntese dos Impactos no Pólo 3 -

Complexo do Brasília Palace .................................. 37

Quadro 5 - Matriz de Interação - Pontão do Lago Sul ......................... 44

Quadro 6 - Síntese dos Impactos no Pólo 11 - Pontão do Lago Sul ...... 45 


\section{SUMÁRIO}

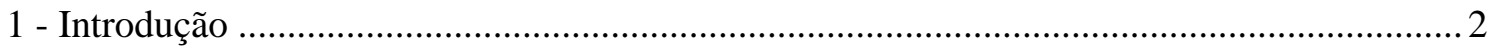

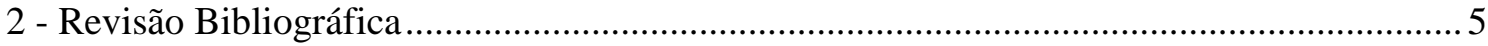

2.1 - Turismo, Meio Ambiente e Desenvolvimento Sustentável ........................................ 5

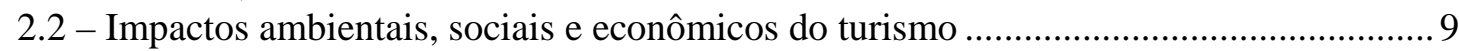

2.3 - Avaliação de Impactos Ambientais ........................................................................... 15

2.4 - Planejamento turístico como ferramenta para o Desenvolvimento Sustentável ........... 17

3 - Caracterização do Objeto de Estudo ......................................................................... 19

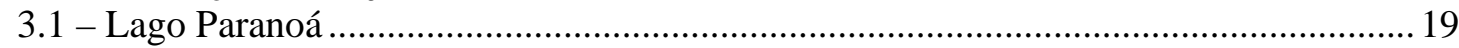

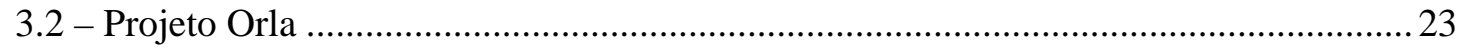

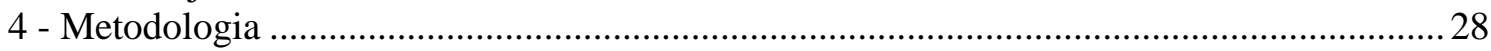

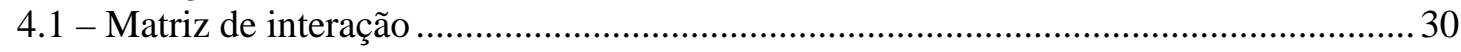

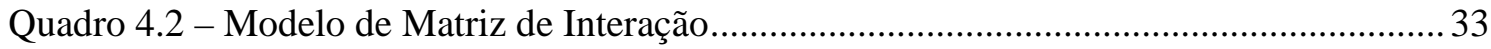

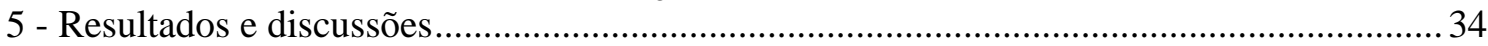

5.1 - Pólo 3 - Complexo do Brasília Palace ......................................................................... 34

Quadro 5.3 - Matriz de Interação - Complexo do Brasília Palace............................................ 36

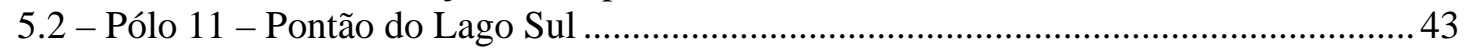

Quadro 5.5 - Matriz de Interação - Pontão do Lago Sul......................................................... 44

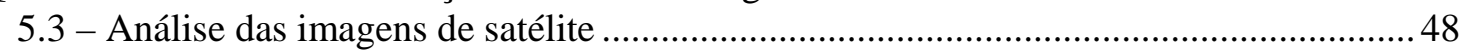

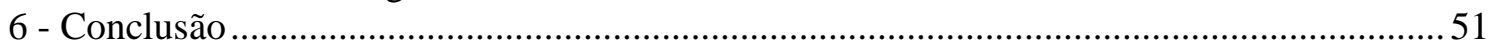




\section{1 - INTRODUÇÃo}

O turismo, pela natureza de suas atividades e pela dinâmica de crescimento nos últimos anos, é um dos segmentos da economia que pode atender de forma completa e de maneira rápida a vários desafios existentes, como, por exemplo, gerar empregos e divisas proporcionando a inclusão social. Além disso, o turismo deverá transformar-se em um agente da valorização e conservação do patrimônio ambiental, cultural e natural, fortalecendo o principio da sustentabilidade.

Assim, é inegável a preocupação que o turismo deve ter em relação ao meio ambiente, pois os recursos naturais servem como base da atividade turística e a garantia da qualidade e proteção ao meio ambiente são de extrema importância para manutenção de um empreendimento turístico.

Paralelamente ao desenvolvimento do turismo surgem efeitos que afetam negativamente a vida das comunidades, sendo necessárias ações específicas para combatê-los ou minimizá-los. Tais efeitos tornam-se ainda mais preocupantes quando incidem sobre áreas de frágil equilíbrio ambiental, como aquelas à beira de corpos hídricos.

É perceptível a atração que os recursos hídricos exercem sobre as pessoas, pois, de maneira geral, quando planejam suas férias ou simplesmente o lazer do final de semana, as pessoas buscam, na maioria das vezes, locais que envolvam água tais como piscinas, lagos, rios, cachoeiras, etc. Com isso, o recurso hídrico presente no local torna-se o principal atrativo do empreendimento turístico, o que leva à necessidade de sua conservação.

Porém, há empreendimentos nos quais o que se vê é a quase total despreocupação para manter a integridade do ecossistema envolvente, o que 
reforça a necessidade de planejamento através de políticas locais para preservação da qualidade das águas utilizadas para turismo e lazer.

Os danos ambientais provocados pelo desenvolvimento descontrolado e sem planejamento do turismo podem causar poluição, degradação da paisagem, destruição da fauna e da flora, entre outros; o que resulta na redução drástica de atividades de recreação e lazer, acarretando o afastamento de turistas.

Diante de tudo isso, conclui-se que a utilização de recursos hídricos como atrativos turísticos requer cuidados e planejamento. Ainda mais quando este recurso se trata de um lago urbano sensível às modificações e ações impostas pela ocupação humana em suas margens.

É o caso do Lago Paranoá, em Brasília. O lago foi formado artificialmente pelo represamento do rio Paranoá e tem como funções iniciais, a correção climática do Distrito Federal, além da utilização para recreação e paisagismo. A condição de cenário paisagístico associada aos demais usos como a prática de esportes náuticos, a pesca, o lazer e a recreação demonstram o grande potencial turístico do Lago Paranoá.

Para atender a este potencial e integrar o Lago aos planos turísticos da capital federal, foi desenvolvido, em meados da década de 90, o Projeto Orla. Este projeto busca o melhor aproveitamento das margens do Lago, tornando-o acessível à maioria da população local, por meio da divisão da orla em onze grandes pólos comerciais, em uma tentativa de organizar a ação turística nas margens do Lago. Porém, qualquer ação de turismo em um ambiente tão frágil quanto o Lago Paranoá deve se preocupar com a preservação do meio ambiente natural.

A garantia da sustentabilidade ambiental nos empreendimentos turísticos se dá, principalmente, pela realização de planejamento ambiental e turístico prévio das 
ações a serem realizadas. E esse planejamento deve buscar garantir a perenidade do ambiente natural, minimizando os impactos negativos.

Partindo dessa hipótese, este trabalho tem como objetivo analisar o Projeto Orla à luz do Desenvolvimento Sustentável, verificando se o seu projeto se preocupa em ser um empreendimento que aplica os princípios da sustentabilidade. Além disso, pretende-se identificar as características naturais do Lago Paranoá, apontando os fatores limitantes e os favoráveis à implantação de equipamentos turísticos no local e, avaliar os possíveis impactos causados pela implantação do Projeto Orla.

O estudo está dividido em seis capítulos. O primeiro refere-se a introdução da temática e a delimitação do presente trabalho. O capítulo dois apresenta a base conceitual e teórica que permeia as atividades de turismo e suas inter-relações com o meio ambiente, técnicas de avaliação de impactos e planejamento de ações turísticas.

O terceiro capítulo descreve o Lago Paranoá, em seus aspectos físicos e os usos de suas margens. Traz também, um detalhamento da proposta inicial do Projeto Orla.

No capítulo quatro elaborou-se a metodologia para análise e avaliação dos impactos. Onde foram detalhadas as técnicas de avaliação ambiental utilizadas na pesquisa e descrita as fontes das imagens aéreas das margens do Lago Paranoá.

Os resultados desta avaliação são apresentados e discutidos nos capítulos 5 e 6 , sendo que neste último faz-se considerações a respeito da relevância do estudo e as recomendações formuladas a partir da análise do Projeto Orla. 


\section{2 - REVISÃo BIBLIOGRÁFICA}

\section{1 - Turismo, Meio Ambiente e Desenvolvimento Sustentável}

$\mathrm{Na}$ segunda metade do século $\mathrm{XX}$, o turismo registrou um crescimento grandioso como fenômeno social e como fator poderoso de desenvolvimento econômico em áreas receptoras, fator devido principalmente ao grande desenvolvimento tecnológico vivido nas áreas de comunicação e transporte neste período.

Em regiões onde há empreendimento turístico, as mudanças nas estruturas socioeconômicas são perceptíveis e podem ser notadas quanto às novas atividades, aos novos promotores, novas formas e ritmos de trabalho e distribuição dos rendimentos (CAVACO. In: RODRIGUES [org], 2001). Isso se dá, principalmente, pela necessidade da instalação da infra-estrutura turística.

Segundo BARRETO (2003):

"Infra-estrutura turística refere-se ao conjunto de bens e serviços que estão à disposição do turista, como parte integrante, fundamental ou acessória, do fenômeno turístico. A infra-estrutura turística de um núcleo abrange a infraestrutura de acesso, a infra-estrutura urbana básica, os equipamentos e serviços de apoio e os recursos turísticos. A soma e o inter-relacionamento desses elementos será a infra-estrutura que a cidade possui para o turismo".

Desse modo pode-se dizer que:

- Equipamentos turísticos são aquelas instalações básicas para o turismo, sem as quais ele não existe. São construídas quase que exclusivamente por causa dele, ex: hotéis, alojamentos extra-hoteleiros, transportadoras marítimas, aéreas ou terrestres, agências de viagens e de transportes.

- Serviços turísticos são aqueles serviços que justificam a sua existência quase que exclusivamente em virtude do turismo. Podem requerer 
equipamento ou ser oferecidos por autônomos, ex: guias, hospedagem, transporte, recreação etc.

- Equipamentos de apoio são aquelas instalações que existem para atender a outras necessidades da comunidade, mas que são de muita utilidade (algumas imprescindíveis) para o turismo, ex: postos de gasolina, rede gastronômica, rede de diversões, hospitais, farmácias, bancos etc.

- Serviços de apoio são aqueles que atendem a outros segmentos da sociedade, mas são também usados pelo turista, ex: alimentação, assistência médica, serviços mecânicos e de socorro, bombeiros, telefones etc.

- Infra-estrutura de acesso são as estradas, os aeroportos ou portos, que permitem acesso ao núcleo.

- Infra-estrutura urbana básica são as ruas, as guias, água, esgoto, luz, asfalto, limpeza pública etc.

A concentração de equipamentos turísticos em determinados locais contribui para a massificação da atividade, tornando-a própria de uma sociedade de consumo e organizada de forma industrial, no sentido de que o turismo apropria-se e explora a natureza e as sociedades locais. Muitas vezes, o que se percebe é a utilização nãosustentável, até o esgotamento, de suas fontes de matérias-primas e a seguinte transferência para outros locais de exploração.

A inter-relação entre o turismo e o meio ambiente é incontestável, uma vez que este último constitui a "matéria-prima" da atividade. E, o que se observa é que o turismo e meio ambiente não têm se caracterizado por um relacionamento equilibrado. Contudo é imprescindível estimular o desenvolvimento harmonioso e 
coordenado do turismo, pois se não houver simetria com o meio ambiente, a atividade turística comprometerá sua própria sobrevivência. É preciso que o turismo e o meio ambiente encontrem um ponto de equilíbrio, a fim de que a atratividade dos recursos naturais não seja a causa da sua degradação (RUSCHMANN,1997).

Assim, FURLAN (1999) acredita que todo turismo deveria ser ecológico no sentido de que para usufruir a natureza é preciso ter um conhecimento prévio do ambiente a ser colocado à disposição do uso turístico. Todo turismo deveria se pautar no funcionamento da natureza e nos seus limites ecológicos ao projetar infraestrutura e equipamentos turísticos. Qualquer tipo de turismo tem de se adequar às fragilidades do meio e ser capaz de gerir e controlar impactos ambientais.

Para que a atividade turística se desenvolva de forma estável faz-se necessário conhecer como diferentes interesses, tanto da entidade promotora do turismo quanto do turista, podem pressionar diferentemente o processo de turismo. Assim, a partir de uma visão integrada de pólos de interesses, o turismo pode ser visto como um processo completo, que vai desde a divulgação correta da imagem do local a ser alcançado, a permanência e satisfação do turista até a sua volta ao local de origem, de modo que a localidade turística permaneça conservada no longo prazo. Ou seja, as condições que garantem a perenidade do investimento turístico são o planejamento prévio e a análise prévia da sustentabilidade local (FARIA, 2001).

O conceito de sustentabilidade está intimamente ligado ao de desenvolvimento sustentável, que de acordo com a Comissão Mundial sobre o Meio Ambiente e Desenvolvimento - CMMAD (1991) pode ser entendido como:

"um processo de transformação no qual a exploração dos recursos, a direção dos investimentos, a orientação da evolução tecnológica e a mudança institucional se harmonizam e reforçam o potencial presente e futuro, a fim de atender às necessidades e aspirações humanas". 
Para o turismo, o conceito de sustentabilidade reflete o desenvolvimento de uma política, de estratégias e ações contínuas, no campo da atividade turística, que promovam a preservação do meio ambiente, evitando assim a degradação dos recursos naturais, cuja base e qualidade depende da manutenção e desenvolvimento deste setor. Há, contudo, que se considerar também as dimensões econômica, cultural e social. Pois, o turismo sustentável só pode ser alcançado também pelo dimensionamento da sustentabilidade econômica e sustentabilidade sociocultural, pensados e colocados em equilíbrio com a sustentabilidade ambiental.

Para SWARBROOKE (2000), turismo sustentável significa "turismo que é economicamente viável, mas não destrói os recursos dos quais o turismo no futuro dependerá, principalmente o meio ambiente físico e o tecido social da comunidade local".

Dentro do conceito de turismo sustentável, como forma permanente de desenvolvimento desta atividade em harmonia com a natureza, deve-se ressaltar que o manejo adequado, cuidadoso e respeitoso para com o meio ambiente, a cultura e as formas de vida das populações locais, não diminui o valor destas áreas como lugares de descanso e lazer, ao contrário, é fator positivo para a atividade turística. (BNB, 1999).

Para entendermos como o turismo pode ser uma atividade verdadeiramente sustentável, é necessário compreender a atividade turística e os impactos que dela decorrem. A relação do turismo com o meio ambiente dá-se principalmente por meio da paisagem, transformada em produto a ser consumido. Invariavelmente são observadas modificações onde ocorre o turismo; e não somente no meio natural, como também em áreas urbanas. 


\section{2 - Impactos ambientais, sociais e econômicos do turismo}

MENDONÇA (1999) é categórica ao assegurar que

"No que diz respeito ao turismo pode-se afirmar, mesmo generalizando, que onde há turismo há degradação ambiental. Onde o turismo é considerado desenvolvido, há concentração de grande número de pessoas que, na realidade, não se interessa muito pelo lugar visitado".

Os empreendimentos turísticos alteram o meio ambiente a fim de adequá-lo às suas necessidades e torná-lo mais atraente do ponto de vista comercial. Segundo OLIVEIRA (2004), "as especificidades dos lugares são transformadas em mercadorias turísticas, pela lógica mercantil, que por meio da publicidade transforma as particularidades locais em objetos de consumo".

A implantação de atividades turísticas implica impactos muito variados e complexos, podendo gerar conflitos em diversas atividades. Por exemplo, pode-se abrir ao turismo uma área que se encontra pouco desenvolvida e de difícil acesso, provocando com isso amplas mudanças ambientais e socioeconômicas que, dependendo da magnitude do projeto, podem ocasionar alterações permanentes que afetam a população local, os recursos naturais, especialmente os solos, as águas, a fauna, a flora e a paisagem (BNB, 1999).

Para RUSCHMANN (1997),

"Os impactos do turismo referem-se à gama de modificações ou à seqüência de eventos provocados pelo processo de desenvolvimento turístico nas localidades receptoras. As variáveis que provocam os impactos têm natureza, intensidade, direções e magnitude diversas; porém os resultados interagem e são geralmente irreversíveis quando ocorrem no meio ambiente natural".

Contudo, tais implicações e alterações podem ser, também, benéficas. Daí, a necessidade de que cada caso seja analisado de acordo com suas particularidades, pois o que é benéfico para uma área pode não o ser para outra.

Os impactos do desenvolvimento turístico podem ser tanto positivos como negativos e podem apresentar-se em diferentes níveis e intensidades. Em alguns 
casos, os impactos não são relevantes e, em outros, comprometem as condições de vida ou a atratividade das localidades turísticas. Em alguns casos tem a área de influência reduzida, já em outros, a área atingida é maior. Outros aspectos a serem observados são o tipo de efeito que o impacto produz, a sua duração e a magnitude.

Conforme o Manual do DNIT (1996) os impactos ambientais são percebidos no nível regional, zonal e na área de influência; em tipos de efeitos: positivos (+) e negativos (-); em magnitude: alta, baixa e moderada; e pela duração: temporária e permanente. Com relação à área de influência, é realizada uma avaliação espacial sobre a localização do efeito; quanto ao tipo de efeito, são observadas características benéficas ou prejudiciais, do tipo qualitativo; a magnitude refere-se ao grau de afetação que apresenta o impacto e qualifica-se de forma quantitativa e, a duração determina a persistência do efeito no tempo.

Percebe-se que tais impactos podem atingir tanto a esfera ambiental, quanto às esferas econômicas e sócioculturais, porém a ênfase maior se dá no estudo dos impactos ambientais. Para SWARBROOKE (2000), isto é compreensível,

"pois os impactos do turismo no meio ambiente são facilmente visíveis, e sabemos que o meio ambiente é um recurso limitado. Contudo, é claro que à medida que a ação do homem dá forma ao meio ambiente físico, qualquer tentativa de administrar o impacto ambiental deve abranger os sistemas econômicos e as necessidades da sociedade em geral e das comunidades locais, em especial".

RUSCHMANN (1997), complementa ao afirmar que:

"O meio ambiente é a base econômica da atividade turística e apresenta oportunidades e limitações. O caráter finito da qualidade dos recursos em ambientes naturais e os custos e benefícios do desenvolvimento turístico para as populações e seu meio trazem à tona uma série de conflitos que necessitam ser resolvidos. Pois, a perpetuação da atratividade dos recursos turísticos é a base do desenvolvimento sustentável do turismo".

Diante desse contexto, a necessidade de avaliação dos impactos causados pelo empreendimento turístico é eminente, pois é esta análise que servirá de base para o planejamento e a tomada de decisões no processo de desenvolvimento da 
atividade turística. Assim, procura-se expor aqui alguns dos principais tipos de

impactos causados pela atividade turística, (ver quadro 2):

Quadro 1: Impactos / Externalidades causados pelo turismo

\begin{tabular}{|c|c|}
\hline $\begin{array}{r}\text { IMPACTOS / EXTER } \\
\text { POSITIVC }\end{array}$ & NEGATIV \\
\hline 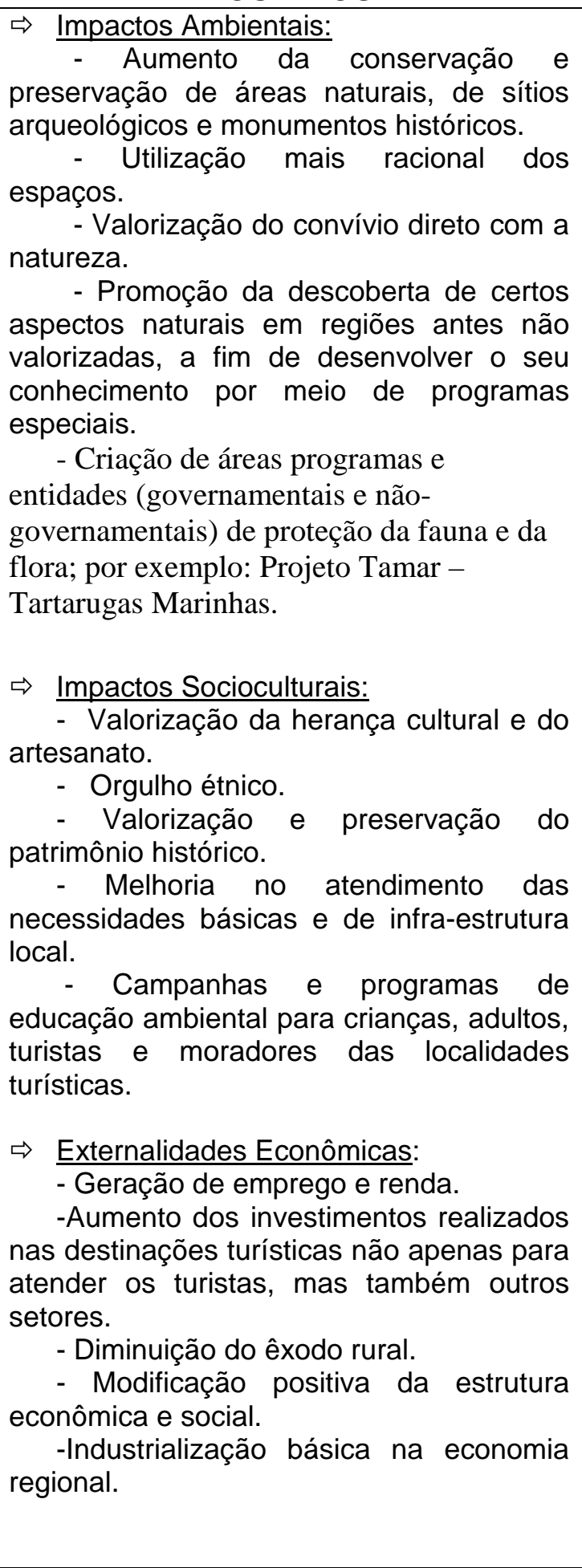 & $\begin{array}{l}\text { द Impactos Ambientais: } \\
\text { - Aumento da utilização e da } \\
\text { necessidade de abastecimento de água } \\
\text { potável. } \\
\text { - Aumento da geração de resíduos } \\
\text { sólidos. } \\
\text { - Aumento da demanda de energia } \\
\text { elétrica. } \\
\text { - Poluição do ar, da água, do solo e } \\
\text { sonora. } \\
\text { - Degradação da flora e da fauna local. } \\
\text { - Reduça da população dos animais, } \\
\text { que tem a sua coleta dirigida ao } \\
\text { atendimento da alimentação dos turistas, } \\
\text { tais como: camarão, caranguejo etc. } \\
\text { - Degradação da paisagem devido a } \\
\text { construções inadequadas. } \\
\text { - Aumento sazonal de população com } \\
\text { diversas implicações sobre a área afetada, } \\
\text { sua infra-estrutura e sua população nativa. } \\
\Rightarrow \text { Impactos Socioculturais: } \\
\text { - Possível mudança de valores e } \\
\text { formas de comportamento tradicionais da } \\
\text { população local, ao ver-se confrontados } \\
\text { com o modo de vida dos turistas. } \\
\text { - Comercialização de festas e } \\
\text { cerimônias tradicionais das populações } \\
\text { locais, como atração aos turistas, com a } \\
\text { possibilidade de perda da identidade por } \\
\text { parte dos nativos e do sentido real de suas } \\
\text { festividades. } \\
\text { - Crescimento da população, com a } \\
\text { concentração espacial e urbanização não } \\
\text { planejada. } \\
\text { - Violação e inobservância às tradições } \\
\text { religiosas. } \\
\text { - Ocorrência do uso indiscriminado do } \\
\text { álcool e das drogas, assim como da } \\
\text { prostituição. } \\
\text { - Degradação da paisagem, de sítios } \\
\text { históricos e de monumentos. } \\
\text { - Migração de pessoas originárias de } \\
\text { os novos pólos turísticos, em busca de } \\
\text { empregos, provocando excedente na oferta } \\
\text { de mão-de-obra e escassez de moradias. }\end{array}$ \\
\hline
\end{tabular}




\begin{tabular}{|c|c|}
\hline $\begin{array}{c}\text { IMPACTOS / EXTERNALIDADES } \\
\text { POSITIVOS }\end{array}$ & $\begin{array}{c}\text { IMPACTOS / EXTERNALIDADES } \\
\text { NEGATIVOS }\end{array}$ \\
\hline $\begin{array}{l}\text { Externalidades Econômicas: } \\
- \text { Mudanças na forma de exploração } \\
\text { econômica da região afetada, com } \\
\text { alterações, tais como da agricultura e da } \\
\text { pesca para a prestação de serviços ao } \\
\text { turista. } \\
- \text { Aumento dos preços dos gêneros de } \\
\text { primeira necessidade, devido ao aumento } \\
\text { da demanda dos turistas. } \\
\text { - Especulação imobiliária. } \\
- \text { Transtornos e efeitos econômicos } \\
\text { negativos, em função da sazonalidade da } \\
\text { demanda turística. } \\
\text { - Concentração de renda, devido a não } \\
\text { distribuição dos benefícios advindos da } \\
\text { atividade turística. }\end{array}$ \\
\hline
\end{tabular}

Adaptado de: BNB(1999) e RUSCHMANN (1997).

Assim, o que se observa é que os impactos causados pelo turismo podem ser tanto positivos quanto negativos, e será o bom planejamento aliado á correta gestão que garantirão a mitigação dos impactos negativos e a potencialização dos impactos positivos na atividade turística.

O turismo pode afetar o meio de forma positiva quando a atividade turística interfere no ambiente natural e colabora na sua conservação, preservação, proteção e mesmo recuperação, pela adoção de medidas regulatórias, pelo manejo e planejamento, além de poder contribuir para a circulação de capital com o desenvolvimento econômico de uma região e pela geração de emprego e renda, o que implica a conseqüente melhoria e manutenção da qualidade de vida das comunidades receptoras.

Por outro lado, os impactos negativos do turismo podem elevar a demanda pelos recursos naturais, sujeitando-os a intensos processos de degradação, poluição em todas as suas formas, além de injustiças e instabilidades econômicas e mudanças socioculturais negativas. 
Com relação aos impactos causados ao meio ambiente, o turismo é apenas uma das atividades que alteram as a paisagens, e é provavelmente menos significativo em seu impacto que outras atividades, tais como a agricultura e a mineração, por exemplo. Contudo, a paisagem natural representa a essência do produto do turismo, daí a necessidade de sua conservação. Para COCOSSIS (apud SWARBROOKE,2000):

"Uma característica importante da interação entre o turismo e o meio ambiente é a existência de fortes mecanismos de realimentação: o turismo com freqüência gera efeitos adversos sobre a quantidade - e a qualidade - dos recursos naturais e culturais, mas ele também é afetado pelo declínio da qualidade e da quantidade desses recursos".

Por serem a matéria-prima do turismo, os recursos naturais são valorizados e protegidos em função do valor econômico que assumem. Dessa forma, a atividade turística pode contribuir para a preservação de espaços naturais. Além disso, o turismo valoriza o meio ambiente e pode gerar uma consciência da necessidade de preservação por parte dos turistas, pois segundo MENDONÇA (1999), uma das funções do turismo sustentável "é a de promover um maior desenvolvimento da subjetividade dos indivíduos, a partir de suas viagens".

Apesar de tornar as pessoas mais informadas sobre o meio ambiente, o que se observa é que o turismo, de forma geral, tem um impacto negativo sobre o meio ambiente natural. E, todas as alterações são visíveis, porém dificilmente mensuráveis. Em razão disso, segundo RUSCHMANN (1997), "para a definição de diretrizes para uma política de turismo voltada para o meio ambiente será preciso determinar quais os limites suportáveis e compatíveis com cada espaço".

Enfim, cada ambiente possui suas características próprias e essas peculiaridades deverão ser contempladas na gestão do turismo, que deverá minimizar os impactos negativos na destinação turística. Contudo, a preocupação 
da gestão do turismo sustentável não é apenas ambiental, mas também econômica, social, cultural, política e administrativa.

No âmbito sociocultural, os principais impactos causados pelo turismo dizem respeito à valorização da cultura de uma comunidade. Se por um lado a atividade turística pode aumentar a auto-estima de uma população, ao dar valor ao seus costumes e/ou artesanato, por outro o turismo pode provocar a mudança de valores dentro de uma cultura e os nativos podem se sentir desvalorizados frente aos hábitos dos turistas.

Tais impactos, geralmente, recebem menos atenção do que o impacto ambiental do turismo. Para SWARBROOKE (2000), isso se dá,

"Por que os impactos socioculturais do turismo geralmente ocorrem de maneira vagarosa e discreta com o passar do tempo. Eles são também em grande parte invisíveis e intangíveis, porém são, em maioria, permanentes, com pouca ou nenhuma oportunidade de revertê-los uma vez ocorrido".

RUSCHMANN (1997) aponta como uma das principais causas para estes impactos negativos o fato de que "o desejo de conhecer os modos de vida de outros povos nem sempre vem acompanhado do devido respeito, da devida consciência do valor e do legítimo interesse por parte dos visitantes".

E a autora complementa:

"Esses e outros impactos sociais comprovam a necessidade de encontrar um equilíbrio entre o desenvolvimento turístico e a proteção da identidade das populações receptoras, que ocorrem em larga escala mas que, por sua subjetividade, são difíceis de mensurar". (RUSCHMANN,1997).

Os impactos econômicos advindos da atividade turística são mais aparentes e presentes nas estatísticas dos pesquisadores. O turismo torna-se a principal atividade econômica da área onde se localiza e, por isso seus impactos no âmbito econômico são estudados com mais cautela. O que se observa é que, apesar de ser a principal fonte de renda para a localidade turística, em alguns casos a renda 
não é distribuída igualmente e nem permanece na região, acarretando fuga de capitais e interrompendo o efeito multiplicador do turismo.

Outra questão de extrema importância é a da sazonalidade da atividade turística que gera transtornos e efeitos negativos à comunidade, pois em determinadas épocas há uma intensa concentração de turistas enquanto em outras épocas os turistas desaparecem. Tal efeito pode ser revertido se houver uma diversificação da atividade econômica realizada na localidade, evitando a dependência exclusiva do turismo.

Enfim, o desenvolvimento do turismo sustentável deve buscar minimizar os efeitos negativos de sua atividade e maximizar os efeitos positivos a fim de alcançar sua eficiência econômica sem comprometer a cultura e/ou o meio ambiente local.

\section{3 - Avaliação de Impactos Ambientais}

Segundo BOLEA (apud MARGULIS, 1990) "as avaliações de impacto ambiental são estudos realizados para identificar, prever e interpretar, assim como prevenir as conseqüências ou efeitos ambientais que determinadas ações, planos, programas ou projetos podem causar à saúde, ao bem-estar humano e ao entorno".

Para tornar-se um efetivo instrumento de auxílio à tomada de decisões, a avaliação de impactos ambientais precisa estar inserida de forma articulada no processo de planejamento a nível mais global. Neste sentido, deve ser efetuada antes do início de um empreendimento, condicionando, juntamente com a avaliação técnico-econômica, a viabilidade do mesmo. Por outro lado, deve acompanhar todo o processo de tomada de decisões, evoluindo da esfera nacional, para a regional e local. 
As técnicas de avaliação de impactos são instrumentos de apoio à realização de estudos de impacto ambiental, cuja utilização deve estar sempre inserida no corpo do método adotado no estudo. Podem ser aplicadas para: ordenar (p.ex., checklists); agregar (p.ex. matrizes, diagramas); quantificar (p.ex., modelos de simulação, análise multi-critérios); representar graficamente (p.ex., overlays, matrizes, diagramas) informações geradas nos estudos. Essas técnicas são importantes para tornar transparentes as informações utilizadas e para facilitar a compreensão dos procedimentos utilizados nos estudos.

A incorporação do conhecimento técnico-científico à avaliação de impacto ambiental exige a utilização de técnicas e modelos específicos de análise da vulnerabilidade/sensibilidade de cada fator natural (solo/subsolo, clima/atmosfera, águas superficiais, águas subterrâneas, biótopo, etc.) e do potencial de danos representado por cada atividade humana.

Algumas das técnicas de apoio mais utilizadas são descritas a seguir ${ }^{1}$.

\section{- LISTA DE CHECAGEM OU "CHECKLIST"}

A Lista de checagem é uma simples listagem dos indicadores do meio natural e do meio antrópico utilizados na análise dos efeitos do projeto, plano ou programa e de suas alternativas locacionais e tecnológicas. Serve de guia para o levantamento dos dados e informações necessários ao estudo, podendo ser acompanhada ou não de uma caracterização de cada indicador listado.

\section{- MATRIZ DE INTERAÇÃO}

A matriz de interação é uma forma de organização de informações, que permite a visualização, em uma mesma estrutura, das relações entre indicadores

1 IBAMA - Instituto Brasileiro do Meio Ambiente e dos Recursos Naturais Renováveis. Avaliação de Impacto Ambiental: agentes sociais, procedimentos e ferramentas. Brasília, 1995. 
relativos ao meio natural e indicadores relativos ao meio antrópico. As matrizes podem ser simples ou complexas, dependendo da quantidade de informações com que se trabalha.

\section{4 - Planejamento turístico como ferramenta para o}

\section{Desenvolvimento Sustentável}

A principal medida preventiva aos impactos negativos do turismo é o bom planejamento. Contudo, todos os planos devem estar associados à visão de sustentabilidade do projeto turístico, em relação ao ambiente do local de desenvolvimento do projeto (BNB, 1999). Além de serem integrados no processo de planejamento e desenvolvimento, estes impactos têm de ser continuamente supervisionados e geridos de modo que quaisquer impactos negativos que surjam possam ser detectados e corrigidos antes de assumirem proporções graves.

No turismo, o plano de desenvolvimento constitui o instrumento fundamental na determinação e seleção das prioridades para a evolução harmoniosa da atividade, determinando suas dimensões ideais, para que, a partir daí, possa-se estimular, regular ou restringir sua evolução. (RUSCHMANN,1997).

A EMBRATUR (2001), em seu Manual de Municipalização do Turismo afirma que:

"O planejamento do turismo leva em conta todos os componentes relevantes do turismo, bem como o planejamento da utilização do espaço físico. Deve ser baseado na comunidade. Isto é, deve-se obter o maior envolvimento possível da comunidade no planejamento, desenvolvimento e tomada de decisões. $O$ processo de planejamento varia em função do tipo de planejamento e das condições locais".

Para FERRETI (2002), a população local é o principal ator no processo de planejamento, pois “o planejamento turístico deve ‘ouvir' essa população e elaborar 
com ela o plano de desenvolvimento local. O planejamento deverá distribuir, o máximo possível, os benefícios econômicos que virão com o turismo, elevando o nível econômico da população e a qualidade de vida, tornando-os mais receptivos".

Assim, para GLOBE'90 (1990) o planejamento surge como uma das premissas básicas para o desenvolvimento de um turismo sustentável:

"Antes de dar início a qualquer projeto principal, devem ser efetuadas análises de planejamento econômico, social e ambiental, dando uma especial atenção a diversos tipos de desenvolvimento do turismo e às formas como estas se podem relacionar com práticas atuais, formas de vida e questões ambientais".

O desenvolvimento sustentável da atividade virá se os elementos ambientais forem considerados em seus três aspectos, através do conhecimento e respeito do meio natural, através da participação ativa das populações nativas tanto no planejamento como na implantação da atividade, e também através da abertura da possibilidade de um maior desenvolvimento da subjetividade dos indivíduos, a partir de suas viagens (MENDONÇA, 1999). 


\section{3 - CARActerizaçÃo do OBJeto de Estudo}

\section{1 - Lago Paranoá}

O Distrito Federal está localizado entre os paralelos de 15030' e 1603' de latitude sul e os meridianos de $47^{\circ} 25^{\prime}$ e $48^{\circ} 12^{\prime}$ de longitude WGr, na Região CentroOeste, ocupando o centro do Brasil e o centro-leste do Estado de Goiás. Sua área é de 5.789,16 km², equivalendo a 0,06\% da superfície do País, apresentando como limites naturais o rio Descoberto, a oeste e o rio Preto, a leste. Ao norte e ao sul, o Distrito Federal é limitado por linhas retas, que definem o quadrilátero correspondente à sua área.

Segundo a classificação de Köppen, o clima do Distrito Federal é tropical, concentrando-se no verão as precipitações. O período mais chuvoso corresponde aos meses de novembro a janeiro, e o período seco ocorre no inverno, especialmente nos meses de abril a setembro.

O Distrito Federal está situado em uma das áreas mais elevadas da Região Centro-Oeste, o Planalto Central, correspondendo ao que restou dos aplainamentos que afetam esta região. Estes aplainamentos caracterizam a forma de relevo mais freqüente nesta área - as chapadas. Essas terras altas constituem $57 \%$ do território e se apresentam como dispersoras das drenagens que fluem para as três principais bacias hidrográficas brasileiras: a Bacia Platina, a Bacia Amazônica e a Bacia SãoFranciscana. Entre as bacias secundárias, está a bacia do Rio Paranoá, tributária do rio São Bartolomeu, onde está situado o lago artificial do Paranoá, criado juntamente com a cidade de Brasília (figura 1). 


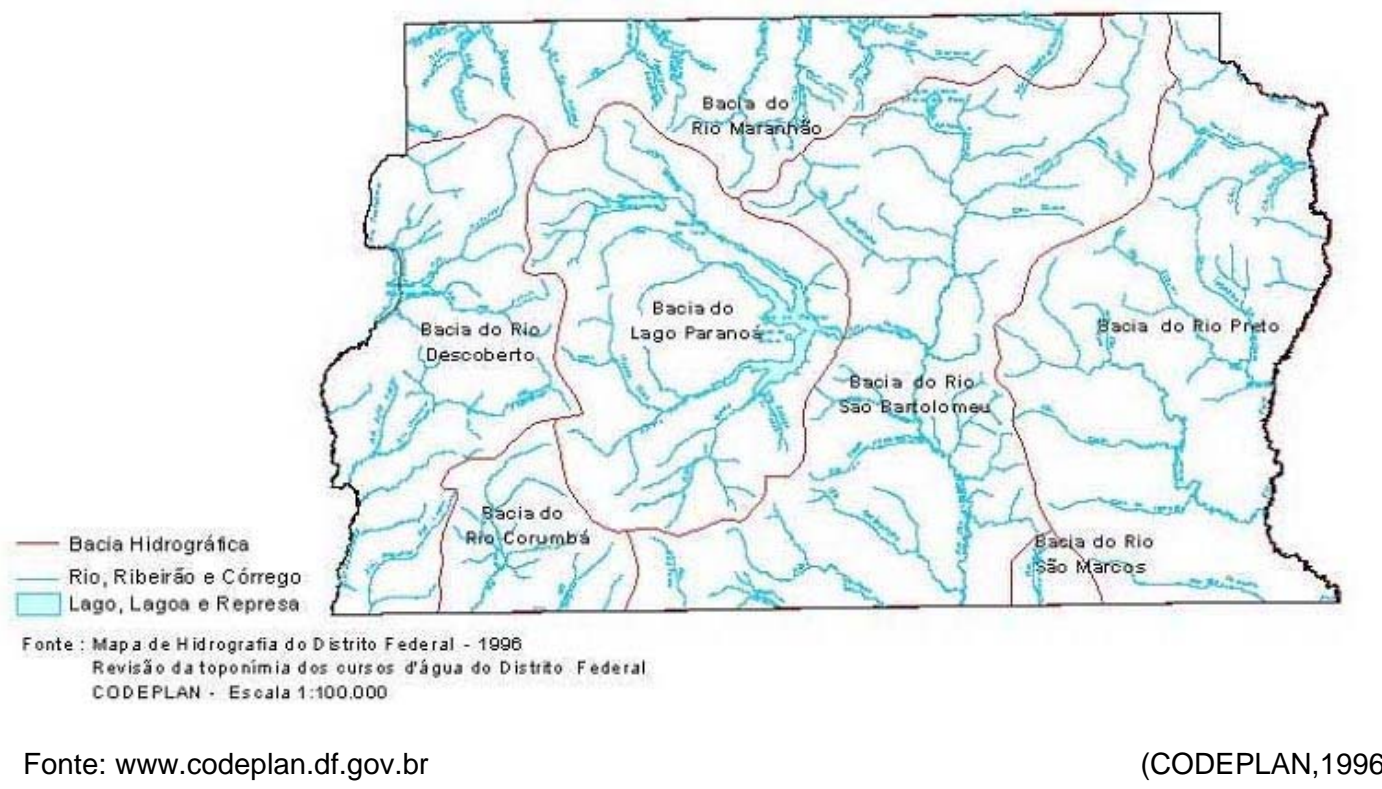

Figura 1: Bacias Hidrográficas do Distrito Federal

O Lago Paranoá é formado pelo represamento do Rio Paranoá e deságua no Rio São Bartolomeu, que faz parte da Bacia Platina. A bacia do Paranoá tem 1046 km² de superfície e é integrada pelas sub-bacias do Córrego do Torto, do Bananal, do Riacho Fundo, do Gama e do Cabeça de Veado. O espelho d'água do Lago Paranoá abrange uma área de $38 \mathrm{~km}^{2}$ com volume de 498 milhões de $\mathrm{m}^{3} \mathrm{e}$ profundidades máxima de 40 e média de 13 metros.

A construção da barragem, que deu origem ao lago, foi iniciada juntamente com a construção de Brasília. Em 1959 foram fechadas as suas comportas e, talvez pela pressa, pois o lago deveria estar cheio para a inauguração, não se procedeu a limpeza da área, seja das matas ciliares ou dos detritos, instalações sanitárias e restos de habitações existentes, e assim as águas do lago se fecharam sobre todos estes resíduos, embora na época já se conhecesse o risco que isto significava em termos de um grave comprometimento da qualidade de suas águas. 
Embora tenha sido criado com finalidades recreativas e para compor a paisagem da capital, o Lago tem um papel extremamente importante dentro do gerenciamento dos recursos hídricos do DF, pois recebe todos os efluentes dos esgotos de Brasília e das cidades-satélites do Núcleo Bandeirante, Guará, Candangolândia, Riacho Fundo e áreas rurais remanescentes e bem como as águas pluviais de toda a bacia que o contém. Por outro lado, embora não seja um reservatório de abastecimento, é das nascentes de alguns de seus tributários que provêm as águas de abastecimento da maior partes da população da cidade.

Dois tipos de uso caracterizam as margens do Lago Paranoá. Na margem oeste, mais próxima do Plano Piloto, predomina as atividades de recreação com a maioria dos lotes destinados a clubes de lazer e hotéis de turismo. Outros usos também estão presentes: as residências do Presidente e do Vice-Presidente da República; a área pertencente à Universidade de Brasília; a grande área pertencente ao Brasília Palace Hotel, destinada à recreação pública, onde se encontram o Museu de Arte de Brasília e a Concha Acústica; a estação de tratamento de lixo SLU na Asa Sul; duas estações de tratamento de esgoto - CAESB, uma em cada Asa.

Já na margem leste, o uso é predominantemente residencial. Existem ainda alguns lotes destinados a clubes, mas esparsos, sem formar um setor específico. Destacam-se nesta margem a Ermida Dom Bosco, a Barragem do Paranoá e as ARIES do Riacho Fundo e do Paranoá Sul. Algumas atividades estão instaladas no chamado "Pontão Sul", próximo à ponte Costa e Silva como restaurantes, aluguel de "jet-ski", etc. Assim, pode-se dizer que o Lago está por completo em uma área de mancha urbana, com sua orla já tendo sido alterada de certa forma, como pode ser visto na figura 2. 

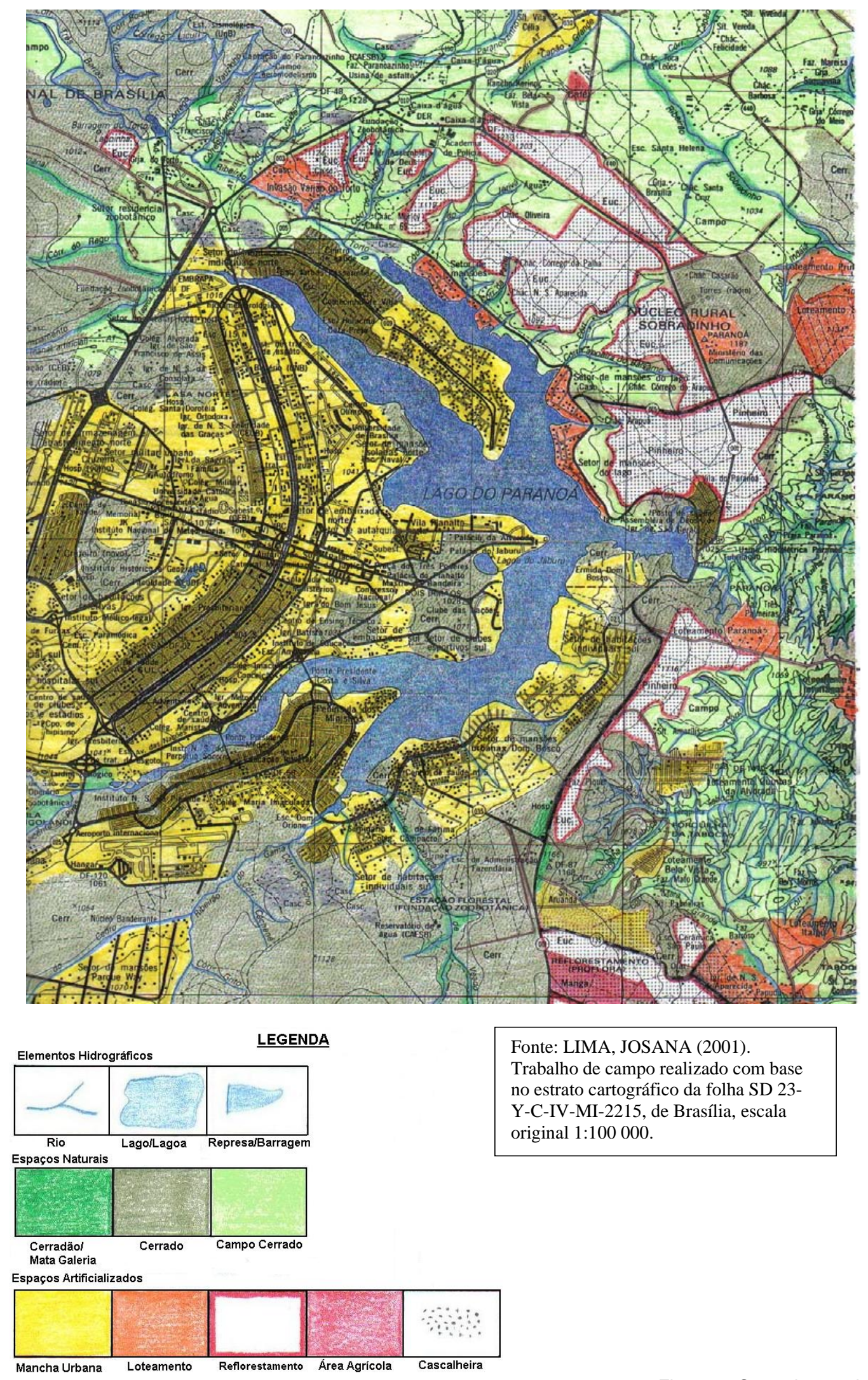

Fonte: LIMA, JOSANA (2001).

Trabalho de campo realizado com base no estrato cartográfico da folha SD 23-

Y-C-IV-MI-2215, de Brasília, escala original 1:100 000. 
A paisagem das margens do Lago é marcadamente horizontal. As construções são baixas, não ultrapassando os 12 metros de altura, situadas em terrenos com curvas de nível suaves. O relevo natural, sem grandes elevações, permite que se observe, constantemente, a linha de cumeada das colinas mais próximas. Sua vegetação nativa - cerrado é composta por arbustos e árvores de pouca altura.

\section{2 - Projeto Orla}

Segundo a Secretaria de Turismo do DF - SETUR, o Projeto Orla nasceu nos primeiros anos da década de 90, como uma proposta de gestão do Lago Paranoá. O Projeto tinha como objetivos o resgate do Lago Paranoá à população de Brasília e ao turista em geral, e o desenvolvimento social e econômico da cidade, juntamente com a recreação e preservação do meio ambiente.

Resgatar a orla do lago para a população de Brasília foi o principal objetivo deste projeto, porém pretendia-se também oferecer novas oportunidades de lazer, atividades náuticas e atrações culturais; além de tornar a orla do lago uma área de convergência, privilegiada, com acesso livre, dando-Ihe um poder de atração, que criaria e manteria um fluxo dinâmico e constante de pessoas.

No entanto, era preciso se atentar para as particularidades de Brasília. Sua concepção urbana, arquitetônica e paisagística, exigia abordagem cuidadosa em relação às interferências necessárias. A manutenção da horizontalidade da paisagem e de sua vegetação nativa remanescente, a preservação de seu entorno paisagístico, a baixa densidade das construções são diretrizes que deviam ser seguidas criteriosamente. 
O método de trabalho adotado procurou identificar, num primeiro momento, as áreas passíveis de ocupação. Posteriormente, foram detectadas suas vocações e, a partir daí, propostas as atividades que seriam implementadas em cada uma das áreas escolhidas. Foram tomados, nesta fase, os cuidados necessários para que houvesse complementaridade entre estas atividades, evitando-se, com isso, a competição entre elas, o que criaria conflitos indesejáveis, inviabilizando algumas delas.

Estas áreas formam, cada uma, um "Complexo de Atrações". Cada um destes Complexos tem seu parcelamento e ocupação do solo propostos de acordo com os usos para ele determinados. Cria-se, assim, uma diferenciação desejável entre eles, enriquecendo a paisagem da orla do lago e permitindo aos usuários a identificação dos complexos, pela sua configuração urbanística e arquitetônica.

Este complexo é interligado por um via, denominada Alameda, que busca propiciar uma continuidade física indispensável à sua implantação do Plano, com atividades de apoio que garantam o interesse dos visitantes em toda sua extensão. Deve apresentar larguras variáveis, formando praças ou caminhos, conforme as atividades oferecidas em seu percurso.

O Projeto Orla também propõe a criação de onze complexos de atividades ligadas ao turismo, ao lazer, a cultura e de caráter institucional, localizados todos ao longo da orla ou em áreas internas, segundo a figura 3. 


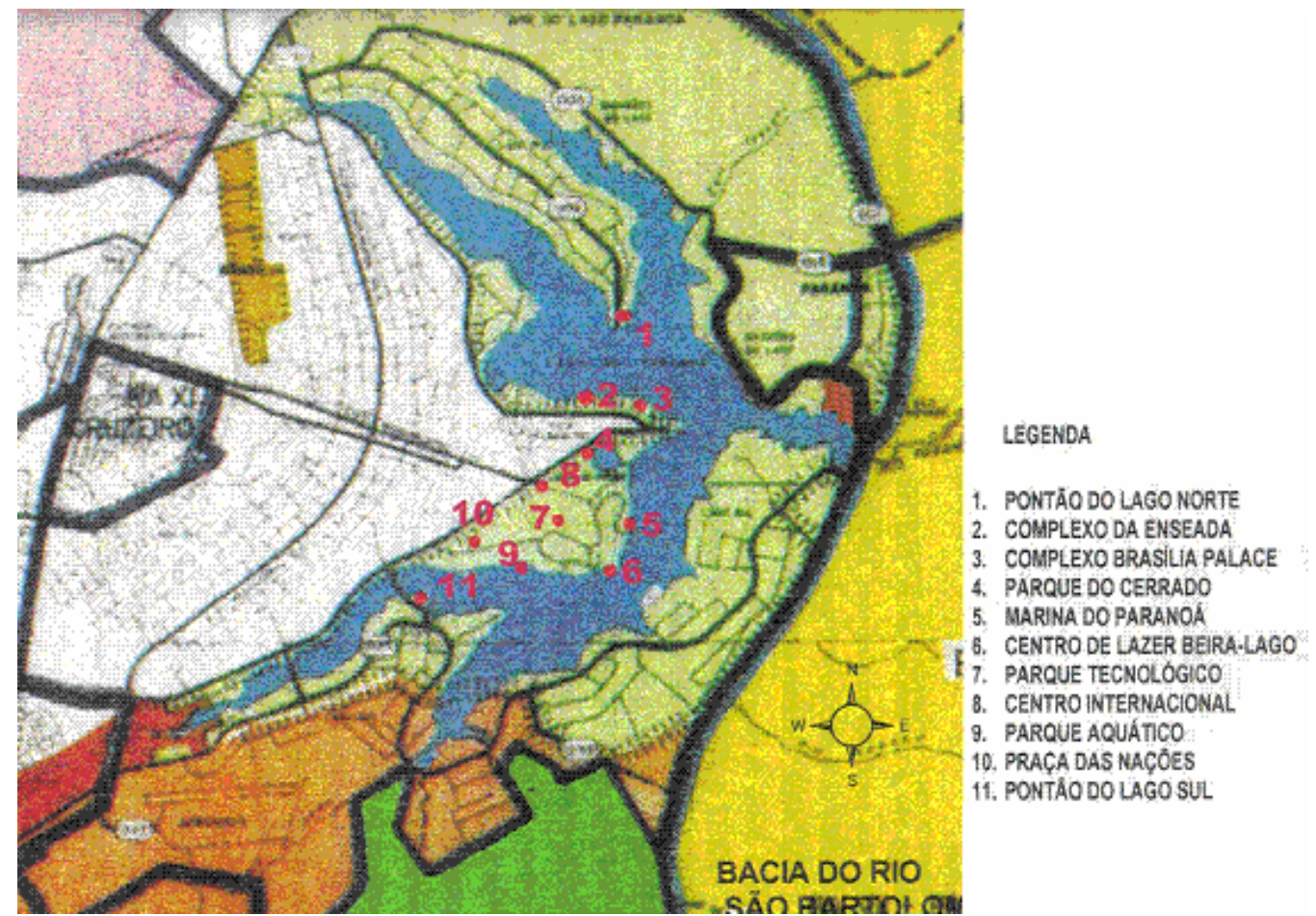

Fonte: Carvalho (1998)

Figura 3: O Projeto Orla e seus pólos

Estes complexos são assim especificados:

- Pólo 1: Pontão do Lago Norte, com uma marina pública, além de pequenos centros comerciais, bares, restaurantes e uma expressiva área verde destinada ao descanso e à recreação infantil.

- Pólo 2: Complexo da Enseada, área destinada principalmente à atividade hoteleira, somando-se ainda atividades como restaurantes, bares, quiosques, pequenos comércios e lazer.

- Pólo 3: Complexo Brasília Palace, que além de um grande hotel, propõe a criação do Museu de Arte de Brasília, de um pavilhão de exposições, escolas de artes plásticas e cênicas, academias de dança e música, etc. Como parte desse complexo está, ainda, a Concha Acústica. 
- Pólo 4: Parque do Cerrado, elemento de ligação entre a orla norte e a orla sul, com função ecológica de preservar a área do Palácio do Jaburu e chamar a atenção para a questão do equilíbrio ambiental do cerrado.

- Pólo 5: Marina do Paranoá, trata-se de um pólo com características marcadamente hoteleiras, servido por uma marina pública e por um passeio, agrupando bares, restaurantes e pequeno comércio de "souvenirs".

- Pólo 6: Centro de Lazer Beira Lago, que busca atender as necessidades cotidianas da população vizinha à área, com comércio de pequeno e médio porte, além de centros de lazer com casas de espetáculos e uma marina.

- Pólo 7: Parque Tecnológico, que prevê um conjunto de edifícios, onde se localizariam um museu de tecnologia, instituições ligadas a ciência, a pesquisa e a tecnologia e um cinema espacial.

- Pólo 8: Centro Internacional, destinado aos organismos internacionais, propõe-se um conjunto de prédios e espaços, distribuídos em torno de um elemento central e comum como uma esplanada ou uma grande praça.

- Pólo 9: Parque Aquático, com comércio de pequeno porte e equipamentos que permitam a realização de atividades desportivas e de lazer, com ênfase para o setor náutico, além da instalação do parque aquático propriamente dito. 
- Pólo 10: Praça das Nações, constituída por um conjunto de pavilhões permanentes representativos das nações que dela participam, buscando mostrar a cultura e a história de diferentes países.

- Pólo 11: Pontão do Lago Sul, não constante do projeto inicial, só foi acrescentado ao Projeto Orla posteriormente por se tratar de uma área já consagrada de lazer.

Atualmente, o Projeto Orla depende do interesse do governo para relançá-lo e tem a sua implementação dificultada em função de depender, essencialmente, de incentivos da iniciativa privada. Dos 11 pólos, há apenas duas áreas consolidadas: 0 pólo 3 - Complexo do Brasília Palace e o pólo 11 - Pontão do Lago Sul. Por terem sido as duas únicas áreas implantadas, esses pólos serão o objeto de análise deste trabalho. 


\section{4 - Metodologia}

A realização da pesquisa se deu através de etapas que consistiram, basicamente, em:

* Revisão bibliográfica a cerca de estudos relativos à atividade turística, meio ambiente e desenvolvimento sustentável. Tais estudos, fundamentados nos principais autores e estudiosos da área, constituíram o embasamento teórico da pesquisa.

* Delimitação da área de estudo, em dois pólos já implantados do Projeto Orla, a saber: Pólo 3 - Complexo do Brasília Palace e o Pólo 11 - Pontão do Lago Sul. Estes dois pólos foram escolhidos com base em informações obtidas junto à Secretaria de Turismo do Distrito Federal - SETUR, na pessoa do Diretor de Programas Ney Lacerda ${ }^{2}$. Segundo o diretor, apenas dois dos onze pólos foram realmente implantados, fato comprovado em trabalho de campo.

* Trabalho de campo, realizado no dia 25/02/2007, que originou registro fotográfico, que ilustra este trabalho e localiza a área de estudo da pesquisa, além de indicar os impactos da atividade turística à luz do referencial teórico e das técnicas para analise de impacto aqui indicadas.

* Análise de imagens de satélite da área de estudo, a fim de identificar os usos do solo nos pólos já implantados do Projeto Orla. Tais imagens foram obtidas através do software Google Earth, na escala de 1:25 000. O Google Earth ${ }^{3}$ é um programa desenvolvido e distribuído pelo Google cuja função é apresentar um modelo tridimensional do globo terrestre, construído a partir de fotografias de satélite obtidas em fontes diversas. Desta forma, o programa pode ser usado simplesmente

\footnotetext{
2 As informações foram obtidas em conversa informal com o Diretor de Programas da SETUR - DF, Ney Lacerda no dia 28/11/2006, na sede da SETUR em Brasília.

O programa utilizado se encontra na versão de testes 4.0.2416, lançada dia 31 de outubro de 2006.
} 
como um gerador de mapas bidimensionais ou como um visualizador de diversas paisagens presentes no Planeta Terra. O Google Earth faz a cartografia do planeta, agregando imagens obtidas de várias fontes, incluindo imagens de satélite, fotografia aérea, e sistemas de informação geográfica sobre um globo em 3D.

* Análise dos possíveis impactos ambientais causados pela implantação dos pólos do Projeto Orla, com base em técnicas de Avaliação de Impactos Ambientais apresentadas pelo Instituto Brasileiro do Meio Ambiente e dos Recursos Naturais Renováveis - IBAMA, em seu manual (IBAMA,1995). A técnica utilizada foi a do checklist associada a um tipo de matriz de interação.

Combinando essas duas técnicas de análise e de agregação de dados, foram desenvolvidos, passo a passo, os seguintes procedimentos básicos para a avaliação dos impactos:

- Identificação de ações ou eventos geradores de impacto, salientando-se aqueles relacionados com a concepção do projeto, aquisição das áreas, parcelamento do solo, desmatamentos, construções, sinalização turística e manutenção do empreendimento.

- Identificação e seleção de parâmetros ambientais, sócioculturais e econômicos de maior relevância, apontados como passíveis de impactos.

- Identificação e descrição dos impactos gerados e classificação destes quanto à sua natureza (positivo ou negativo, temporário ou permanente) e quanto à sua magnitude (fraco, médio ou crítico).

Como resultados da combinação desses itens, foram obtidos os seguintes produtos:

- Matriz de interação elaborada de forma a sistematizar as informações numa mesma estrutura e permitir a visualização das ações responsáveis pelos 
impactos mais significativos. Cada célula da matriz mostra a relação entre uma ação do empreendimento e um parâmetro, qualificando os impactos em positivo ou negativos e em fracos, moderados ou críticos.

- Quadro-síntese com o objetivo de identificar para cada uma das ações do empreendimento a seqüência dos impactos envolvidos e suas características, classificando-os quanto à sua natureza e à sua magnitude.

\section{1 - Matriz de interação}

A partir de uma análise preliminar das características do projeto, foi elaborada uma listagem com as ações impactantes mais significativas que este empreendimento pode gerar. Assim, as ações consideradas de maior relevância na geração de impactos são:

Fase de Planejamento

Concepção do Projeto

Parcelamento do Solo

Fase de Construção

Desmatamento

Infra-estrutura de apoio (estacionamento, vias de acesso, calçadas)

Edificações (Hotéis, restaurantes, shoppings, marinas)

Sinalização turística

Fase de operação

Realização de eventos

A utilização da técnica do checklist possibilitou a elaboração de uma relação de possíveis impactos gerados pelo empreendimento. Esta relação não pretende abranger todos os impactos possíveis de serem alterados, mas apresenta aqueles de elevada representatividade e de fácil identificação por métodos diretos 
(levantamentos de campo e interpretação de fotografias aéreas e imagens de satélite) ou através da análise de dados secundários, resultando na seguinte lista:

Impactos Ambientais

Substituição da cobertura vegetal

Poluição da água

Compactação do solo

Modificação da paisagem

Impactos Sócioculturais

Atendimento às necessidades básicas e de infra-estrutura local

Acesso aos atrativos

Presença de equipamentos turísticos

Impactos Econômicos

Geração de emprego e renda

Aumento do número de empreendimentos turísticos

Especulação imobiliária

Numa matriz bi-dimensional foram relacionados os impactos com as ações relativas ao empreendimento, identificando as interações possíveis. Para uma melhor visualização de uma escala de valores para os impactos, em substituição aos métodos de avaliação numérica, optou-se por utilizar símbolos referentes aos impactos positivos $(\square)$ e negativos: fraco $(\bigcirc)$, moderado $(\odot)$ e crítico $(\bullet)$.

Completada a matriz, pode-se apreciar o conjunto de impactos gerados pelo projeto, destacando-se as ações que provocam os impactos mais significativos e que, portanto, devem ser objeto de maior atenção ou mesmo de substituição por ações alternativas de projeto menos impactantes. Para essa análise foram utilizados também, os quadros-síntese que permitiram uma descrição detalhada dos impactos.

Para a avaliação dos impactos foram adotados os seguintes critérios de análise: 


\section{- Quanto à qualificação:}

- Positivo: impactos cujos efeitos se traduzem em benefício para melhoria da qualidade ambiental de um fator ou parâmetro considerado.

- Negativo: impactos cujos efeitos se traduzem em prejuízo à qualidade ambiental de um fator ou parâmetro considerado.

\section{- Quanto à duração:}

- Temporário: impacto cujos efeitos se manifestam em um intervalo de tempo limitado e conhecido, cessando uma vez eliminada a causa da ação impactante.

- Permanente: impacto cujos efeitos se estendem além de um horizonte temporal conhecido, mesmo cessando a causa geradora da ação impactante.

\section{- Quanto à magnitude:}

- Crítico: impacto cujo efeito resulta em alteração significativamente elevada para um determinado fator ou parâmetro ambiental considerado, podendo comprometer a qualidade do ambiente.

- Moderado: impacto que resulta em alteração medianamente significativa para um determinado fator considerado ou parâmetro ambiental, podendo comprometer parcialmente a qualidade do ambiente.

- Fraco: impacto que resulta em alteração pouco significativa para um determinado fator ou parâmetro ambiental, podendo ser considerados desprezíveis seus efeitos sobre a qualidade do ambiente.

Dessa maneira, a matriz de interação utilizada para a avaliação de impactos neste trabalho é a apresentada a seguir. 
QUADRO 2 - MODELO DE MATRIZ DE INTERAÇÃo

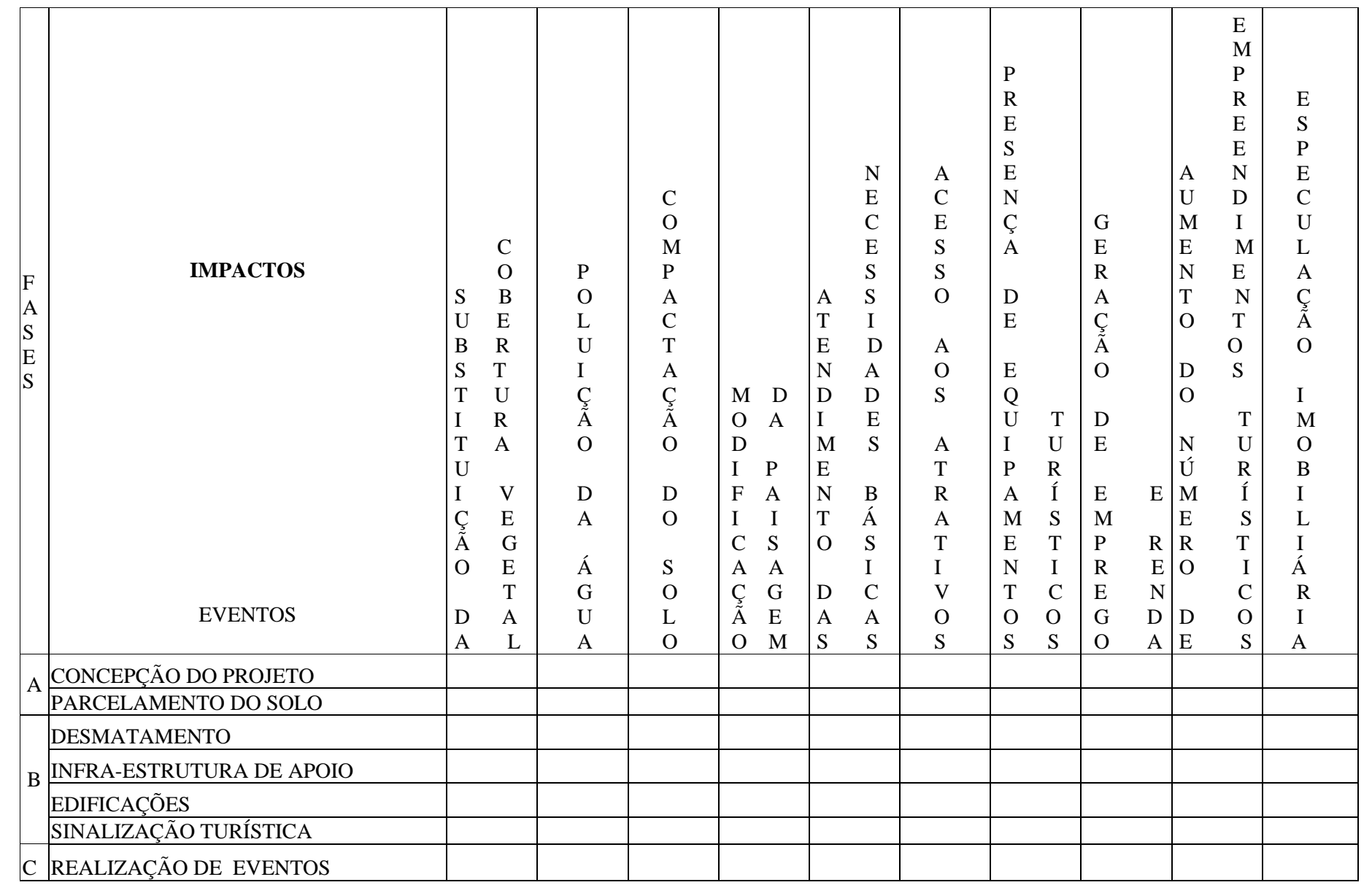

Fases: A (Planejamento) B (Construção) C (Operação)

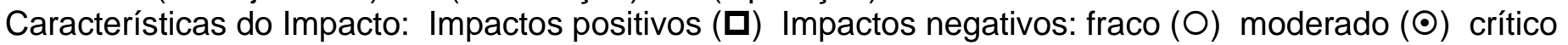




\section{5 - Resultados E discussões}

A análise dos resultados obtidos a partir do trabalho em campo será dividida em duas partes, de acordo com cada pólo do Projeto Orla, para depois ser analisada em conjunto, oferecendo respostas para as perguntas apresentadas nos capítulos anteriores. Assim, serão avaliados primeiramente os impactos causados pela implantação do Pólo 3 - Complexo do Brasília Palace e em seguida, os impactos causados pelo Pólo 11 - Pontão do Lago Sul.

\section{1 - Pólo 3 - Complexo do Brasília Palace}

A proposta para o projeto do Complexo do Brasília Palace visava, principalmente, o resgate do famoso hotel, além de uma "Praça das Artes", tendo como principal atrativo o Museu de Arte de Brasília. Porém, o que se vê atualmente no local em nada se parece com uma "Praça de Artes". O lugar está abandonado à própria sorte e é utilizado pelos moradores da vizinhança, em sua grande maioria para não dizer totalidade - da Vila Planalto, como uma área de lazer, porém sem uma infra-estrutura adequada. Ali é possível encontrar crianças brincando, jovens lavando seus veículos, animais de estimação correndo, adolescentes aproveitando o dia ensolarado, etc (vide figura 4). A Concha Acústica parece inutilizada e as condições do local são precárias. 


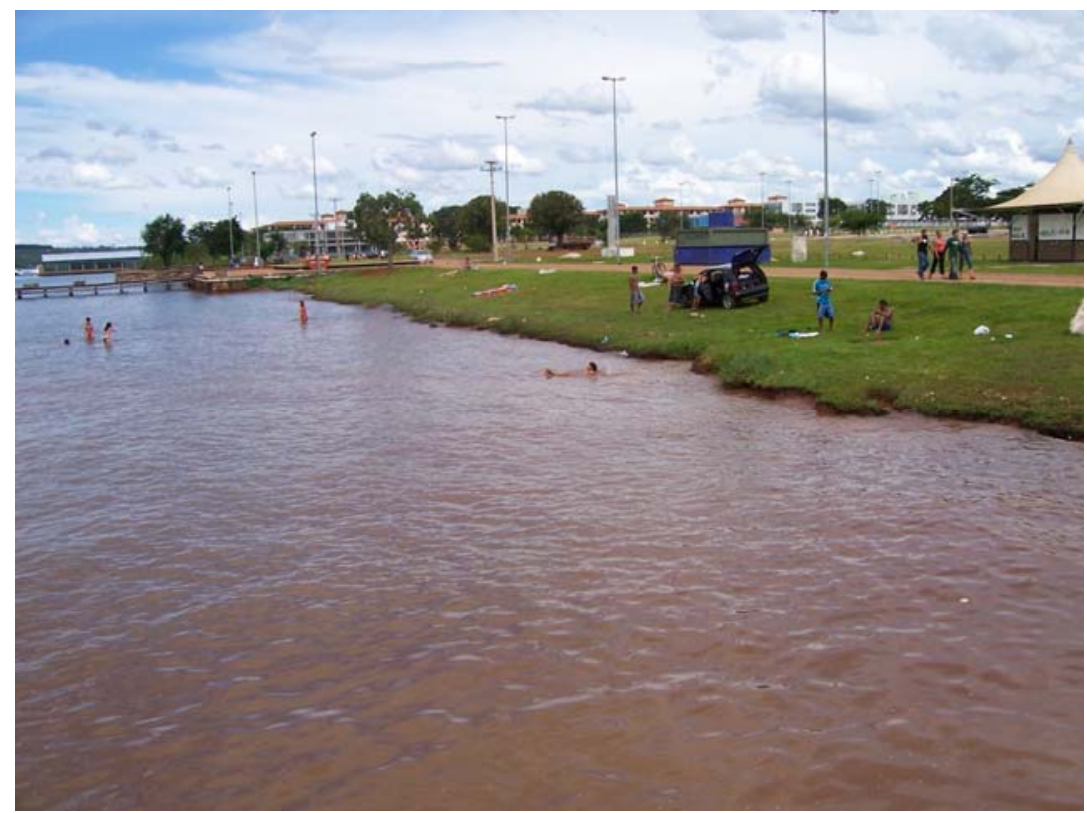

Fonte: LIMA, JOSANA (2007)

Figura 4: Diversão no pólo 3

A avaliação dos impactos, feita por meio da matriz de interação e descrita no quadro-síntese, é apresentada primeiramente. Em seguida, mostra-se uma análise mais aprofundada dos impactos de maior relevância naquele pólo. 


\section{QuAdRo 3 - MATRIZ de INTERAÇão - Complexo do BRAsília PALACE}

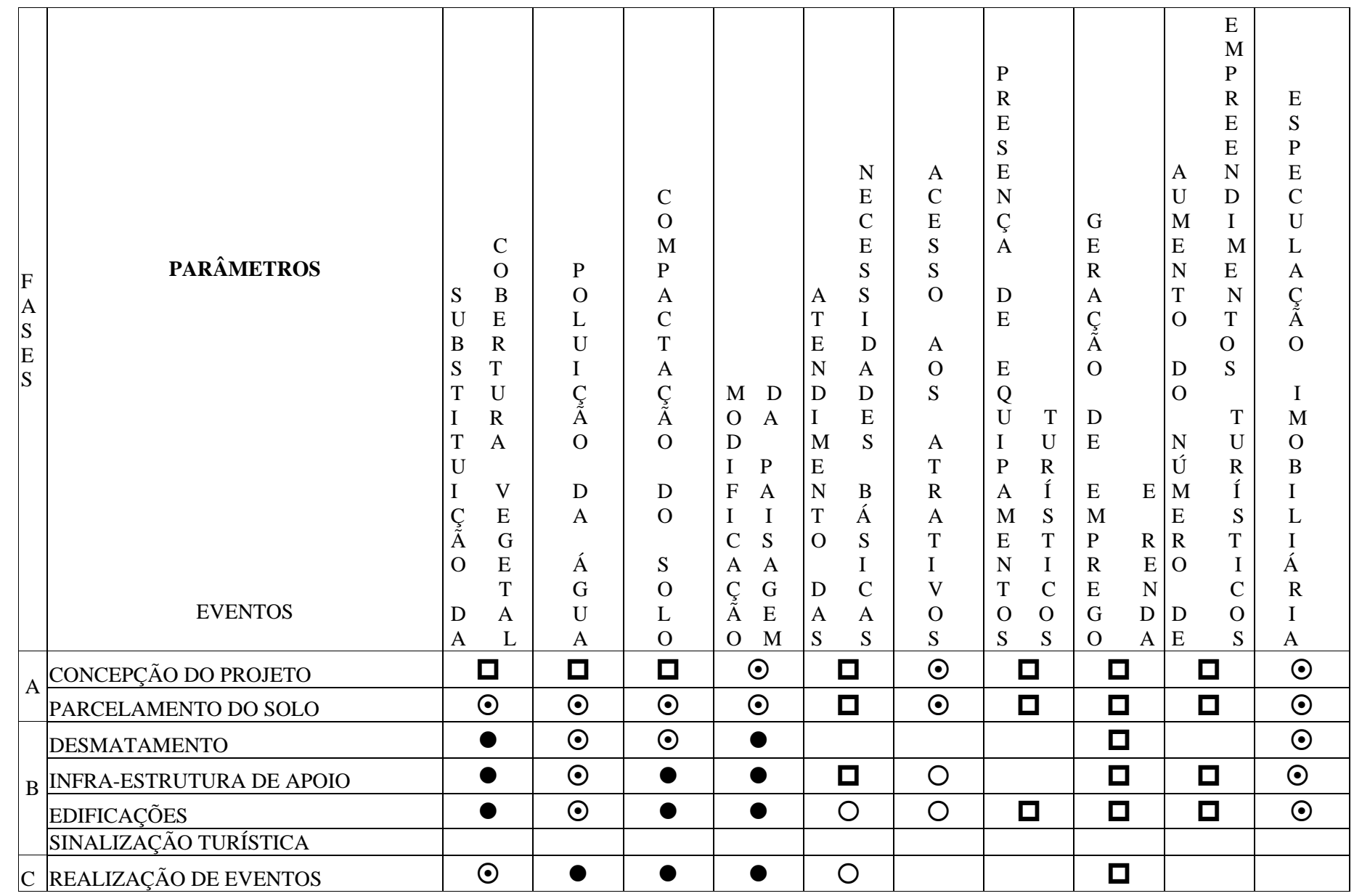

Fases: A (Planejamento) B (Construção) C (Operação)

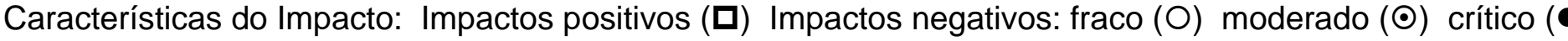


Quadro 4: Síntese dos Impactos no Pólo 3 - Complexo do Brasília Palace

\begin{tabular}{|c|c|c|}
\hline AÇÃO & IMPACTOS & $\begin{array}{l}\text { CARACTERÍSTICAS } \\
\text { DOS IMPACTOS }\end{array}$ \\
\hline Concepção do projeto & $\begin{array}{l}\text { - Proposição de medidas } \\
\text { que busquem a manutenção } \\
\text { da qualidade ambiental, } \\
\text { evitando a poluição da água, } \\
\text { erosão do solo e seus } \\
\text { efeitos. } \\
\text { - Projetos que visam a } \\
\text { alteração significativa da } \\
\text { paisagem, com muitas } \\
\text { construções e espaços } \\
\text { artificializados. } \\
\text { - Oferta de atrativos que } \\
\text { privilegiam apenas a uma } \\
\text { parte da população do DF, a } \\
\text { de alta renda. } \\
\text { - O projeto busca a melhoria } \\
\text { das condições } \\
\text { urbanização nas áreas onde } \\
\text { se localiza, além da geração } \\
\text { de empregos e de atrair } \\
\text { diversos empreendimentos } \\
\text { para o local. }\end{array}$ & $\begin{array}{c}\text { Positivo } \\
\text { Permanente } \\
\text { Moderado } \\
\text { Negativo } \\
\text { Permanente } \\
\text { Moderado } \\
\text { Negativo } \\
\text { Permanente } \\
\text { Moderado } \\
\\
\text { Positivo } \\
\text { Permanente } \\
\text { Moderado }\end{array}$ \\
\hline Parcelamento do solo & $\begin{array}{l}\text { - A escolha das áreas nas } \\
\text { quais se localizariam os } \\
\text { pólos não leva em conta } \\
\text { aspectos como a distância } \\
\text { até a margem do lago, } \\
\text { havendo ocupação em } \\
\text { Áreas de Preservação } \\
\text { Permanente. } \\
\text { - A localização dos atrativos } \\
\text { beneficia apenas parte da } \\
\text { população. } \\
\text { - As áreas escolhidas } \\
\text { beneficiam a instalação de } \\
\text { novos equipamentos } \\
\text { turísticos e estimulam a } \\
\text { especulação imobiliária em } \\
\text { função de suas localizações. }\end{array}$ & $\begin{array}{c}\text { Negativo } \\
\text { Permanente } \\
\text { Moderado } \\
\text { Negativo } \\
\text { Permanente } \\
\text { Moderado } \\
\text { Negativo } \\
\text { Permanente } \\
\text { Moderado }\end{array}$ \\
\hline Desmatamento & $\begin{array}{lrr}\text { - Completa } & \text { substituição da } \\
\text { cobertura vegetal } & \text { por } \\
\text { asfaltamentos, calçadas } & \text { e } \\
\text { construções. Isso aumenta o } \\
\text { escoamento superficial } & \text { e } \\
\text { conseqüentemente } & \text { a } \\
\text { poluição das águas } & \text { e } \\
\text { erosões. } & & \\
\text { - Severa modificação da } \\
\text { paisagem, com ocupação } \\
\text { das margens sem a }\end{array}$ & $\begin{array}{l}\text { Negativo } \\
\text { Permanente } \\
\text { Crítico } \\
\\
\\
\text { Negativo } \\
\text { Permanente } \\
\text { Crítico }\end{array}$ \\
\hline
\end{tabular}




\begin{tabular}{|c|c|c|}
\hline \multirow[t]{2}{*}{ AÇÃO } & IMPACTOS & $\begin{array}{l}\text { CARACTERÍSTICAS } \\
\text { DOS IMPACTOS }\end{array}$ \\
\hline & $\begin{array}{l}\text { preocupação com a } \\
\text { distância mínima exigida. } \\
\text { - O desmatamento facilita o } \\
\text { parcelamento do solo para } \\
\text { outros objetivos, } \\
\text { estimulando a especulação } \\
\text { imobiliária. }\end{array}$ & $\begin{array}{c}\text { Negativo } \\
\text { Permanente } \\
\text { Moderado }\end{array}$ \\
\hline $\begin{array}{l}\text { Construção de Infra- } \\
\text { estrutura de Apoio }\end{array}$ & $\begin{array}{l}\text { - Completa substituição da } \\
\text { cobertura vegetal por } \\
\text { asfaltamentos, calçadas e } \\
\text { construções. } \\
\text { - Severa modificação da } \\
\text { paisagem, com ocupação } \\
\text { das margens sem a } \\
\text { preocupação com a } \\
\text { distância mínima exigida. } \\
\text { - Sem preocupação com o } \\
\text { acesso dos portadores de } \\
\text { necessidades especiais. } \\
\text { - A construção de novas } \\
\text { infra-estruturas gacra gera } \\
\text { empregos e possibilita o } \\
\text { surgimento de novos } \\
\text { empreendimentos turísticos } \\
\text { na área, aumentando a } \\
\text { especulação imobiliária. }\end{array}$ & $\begin{array}{c}\text { Negativo } \\
\text { Permanente } \\
\text { Crítico } \\
\text { Negativo } \\
\text { Permanente } \\
\text { Crítico } \\
\text { Negativo } \\
\text { Temporário } \\
\text { Fraco } \\
\\
\text { Negativo } \\
\text { Permanente } \\
\text { Moderado }\end{array}$ \\
\hline Construções de Edificações & 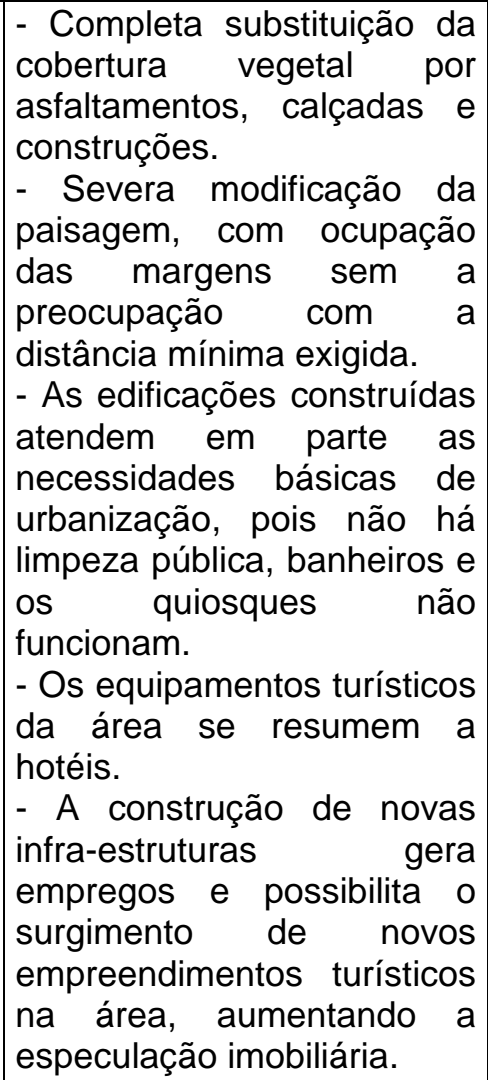 & $\begin{array}{c}\text { Negativo } \\
\text { Permanente } \\
\text { Crítico } \\
\text { Negativo } \\
\text { Permanente } \\
\text { Crítico } \\
\\
\text { Negativo } \\
\text { Temporário } \\
\text { Fraco } \\
\\
\\
\text { Negativo } \\
\text { Temporário } \\
\text { Fraco } \\
\text { Negativo } \\
\text { Permanente } \\
\text { Moderado }\end{array}$ \\
\hline
\end{tabular}




\begin{tabular}{|c|l|c|}
\hline AÇÃO & \multicolumn{1}{|c|}{ IMPACTOS } & $\begin{array}{c}\text { CARACTERÍSTICAS } \\
\text { DOS IMPACTOS }\end{array}$ \\
\hline Sinalização Turística & $\begin{array}{l}\text { Não foi encontrado nenhum } \\
\text { tipo de sinalização turística. }\end{array}$ & $\begin{array}{c}\text { Negativo } \\
\text { Temporário } \\
\text { Crítico }\end{array}$ \\
\hline Realização de eventos & $\begin{array}{l}\text { Grandes eventos } \\
\text { realizados às margens do } \\
\text { lago podem comprometer } \\
\text { ainda mais as condições da } \\
\text { água e do solo no local. } \\
- \text { Geração de emprego. }\end{array}$ & $\begin{array}{c}\text { Positivo } \\
\text { Temporário }\end{array}$ \\
\hline
\end{tabular}

Fonte: Síntese dos resultados apurados pela Matriz de Interação

De acordo com o apresentado, percebe-se que apesar da proposta do Projeto Orla prever a manutenção da qualidade ambiental, a manutenção da vegetação nativa remanescente e a preservação do entorno paisagístico, o local foi modificado e a cobertura vegetal completamente substituída por calçadas e estacionamentos, além das construções (figura 5). As margens do lago estão erodidas ou foram barradas com uma espécie de muro. Tudo isso aumenta o escoamento superficial das águas pluviais e, conseqüentemente, a poluição do lago. A água do lago também é comprometida pelo óleo oriundo das embarcações presentes no local, assim como, pela ação de vários freqüentadores que utilizam o Lago Paranoá para lavar seus veículos.

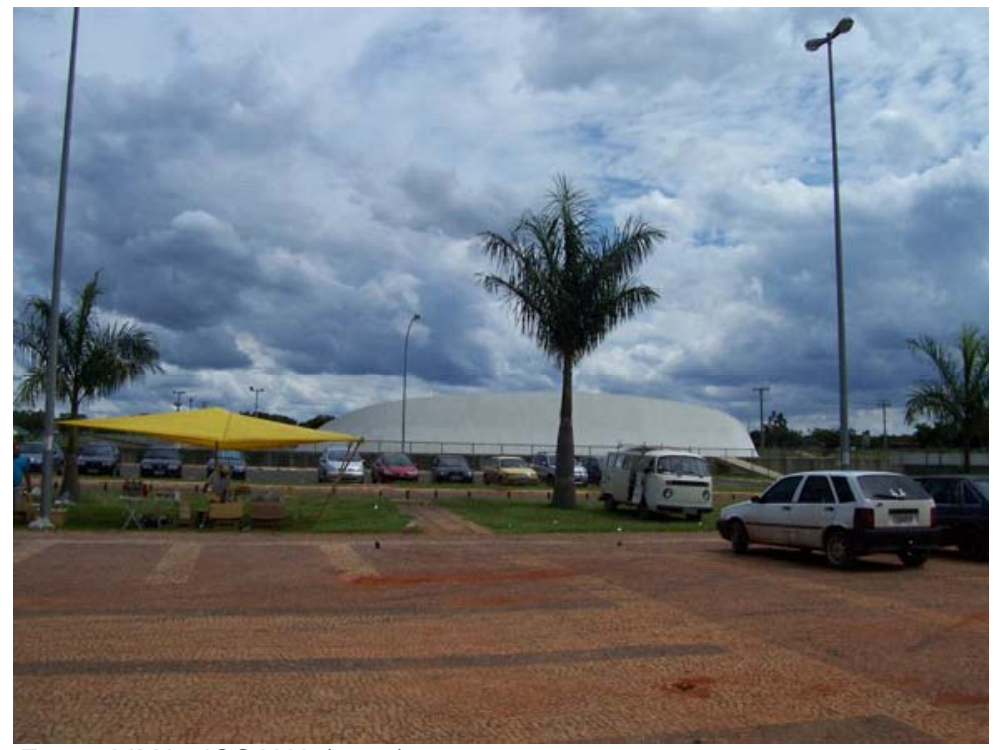

Fonte: LIMA, JOSANA (2007)

Figura 5: Substituição da cobertura vegetal no pólo 3 
Outro fator que compromete a qualidade ambiental no local é a falta de infra-estrutura urbanística, como limpeza pública, segurança e banheiros públicos. No local, há lixo por toda parte (figura 6) e seu depósito final acaba por ser o lago. Não há banheiros públicos na proximidade, apesar de haver estrutura física e indícios de que os banheiros já estiveram em funcionamento, porém atualmente as portas dos banheiros encontram-se soldadas. Quanto à segurança, não há garantias dentro da água nem em terra firme. Apesar do grande número de banhistas não há nenhum salva-vidas por perto e, fora da água, não há policiamento de forma nenhuma.

Não há infra-estrutura turística no local. Os visitantes não encontram Centros de Atendimento ao Turista ou qualquer tipo de informação que os auxiliem e enriqueçam sua visita. Ao longo de todo o trajeto para se chegar ao pólo, não foi encontrado nenhum tipo de sinalização que indique onde ficam e quais são os atrativos do local. Não há também, serviços turísticos como restaurantes, lanchonetes ou de qualquer outro tipo que proporcione conforto ao visitante. Até o principal atrativo do local, a Concha Acústica, não colabora para a composição da paisagem, sua estrutura é toda de concreto e o palco não permite que se tenha visão para o Lago. 


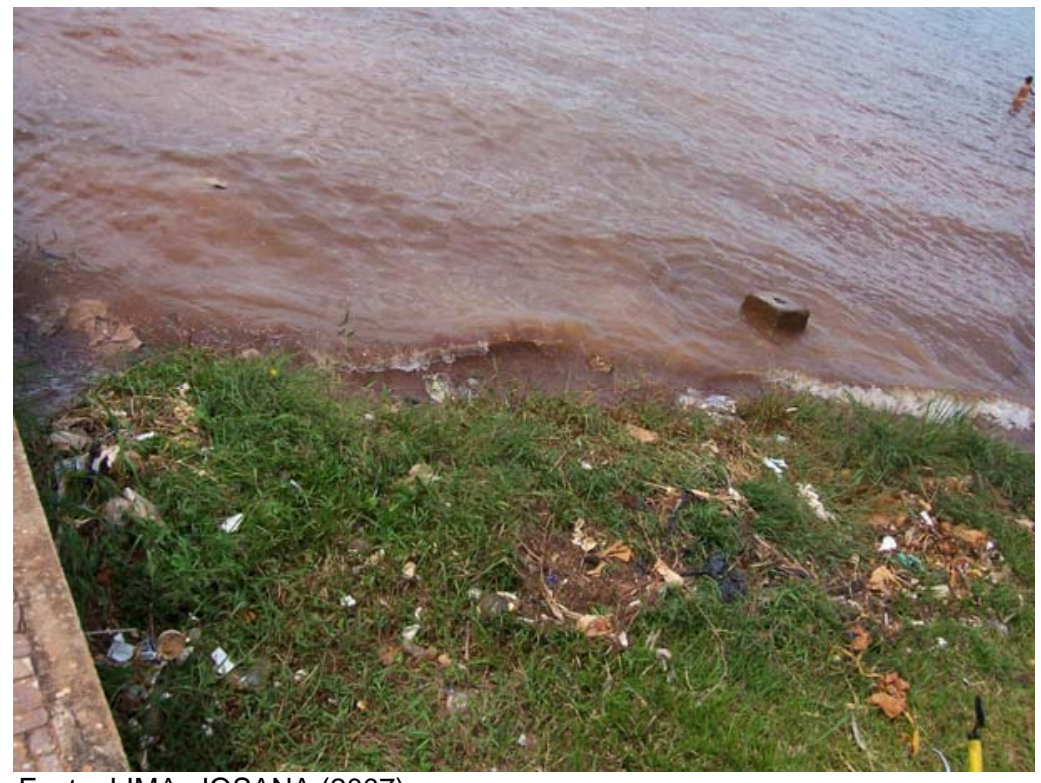

Fonte: LIMA, JOSANA (2007)

Figura 6: Lixo nas margens do lago

No que diz respeito a acesso ao atrativo, tal acesso foi analisado sob diversos aspectos: quanto a valor cobrado, quanto à facilidade de acesso por meio de transportes, quanto à sinalização turística e quanto ao acesso para portadores de necessidades especiais. No tocante a valor, não há cobrança e o acesso às margens do Lago é livre. Já quanto aos outros aspectos, o acesso é dificultado uma vez que não as linhas de ônibus que passam no local têm horários e itinerários pouco divulgados, não há sinalização turística e os portadores de necessidades não têm condições de chegarem às margens do lago, pois não há rampas que facilitem o acesso ao local.

É possível perceber também que não houve respeito às leis ambientais quanto à ocupação das margens do lago, pois segundo a resolução 302 do Conselho Nacional do Meio Ambiente - CONAMA, há que se respeitar uma distância mínima de 30 metros para a supressão da vegetação e/ou modificação da paisagem. No lago, este limite não é respeitado já que as construções por vezes, adentram suas águas, e esta situação é recorrente ao longo de toda a orla (figura 7). 


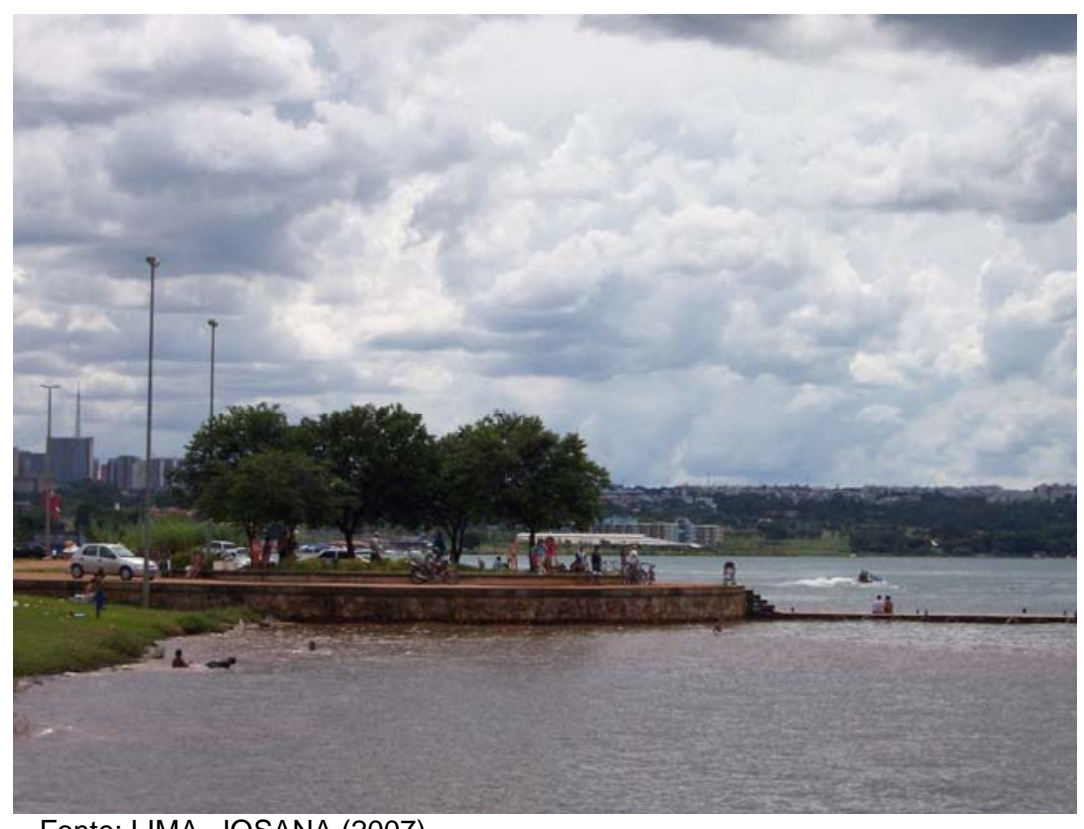

Fonte: LIMA, JOSANA (2007)

Figura 7: As construções adentram o Lago

Nas imediações do pólo 3 do projeto Orla, o que chama atenção é a quantidade de construções, principalmente de edifícios residenciais (figura 8). São locais que deveriam ser de livre acesso ao público em geral e atualmente são vendidas para uma pequena parcela da população, àquela com maior poder aquisitivo. O preocupante é que no futuro, a convivência entre os moradores desses edifícios e os freqüentadores do pólo 3 pode ser comprometida em função das diferentes funções que cada grupo atribui para aquela área, enquanto para uns o Lago significa tranqüilidade e o local que escolheram para morar, para outros o Lago tem sinônimo de lazer e local para festas e eventos. 


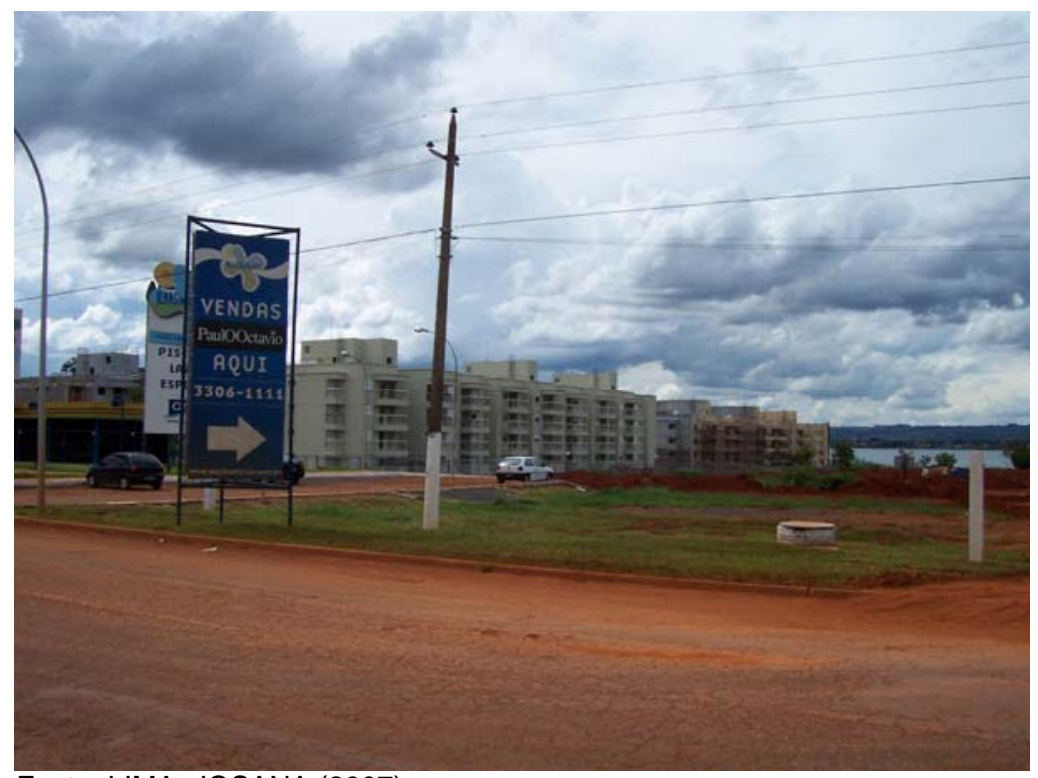

Fonte: LIMA, JOSANA (2007)

Figura 8: Especulação imobiliária

\section{2 - Pólo 11 - Pontão do Lago Sul}

O pólo 11 foi incluído posteriormente na proposta do Projeto Orla por se tratar de uma área já consolidada de lazer. Situado às margens do lago Paranoá e junto à ponte Costa e Silva, o Pontão foi construído para desenvolver o turismo cultural, gastronômico, de negócios e de entretenimento na região e, hoje, já se transformou em um dos pontos mais importantes e atrativos de Brasília. Utilizada principalmente por moradores do lago Sul e de Brasília, é uma área com 134.000 metros quadrados, e que abriga restaurantes, bares, feiras de arte, shows musicais, quiosques e parquinho para crianças. A estrutura ainda oferece estacionamento para mil e duzentos veículos. ${ }^{4}$

Os impactos decorrentes da implantação do pólo encontram-se esquematizados na matriz de interação e no quadro-síntese. Aqueles impactos de maior relevância são comentados em seguida. 


\section{QUADRO 5 - MATRIZ DE INTERAÇÃo - PONTÃo do LAGO SUL}

\begin{tabular}{|c|c|c|c|c|c|c|c|c|c|c|c|}
\hline $\begin{array}{l}\text { F } \\
\text { A } \\
\text { S } \\
\text { E } \\
\text { S }\end{array}$ & $\begin{array}{l}\text { PARÂMETROS } \\
\text { EVENTOS }\end{array}$ & $\begin{array}{ll} & \mathrm{C} \\
& \mathrm{O} \\
\mathrm{S} & \mathrm{B} \\
\mathrm{U} & \mathrm{E} \\
\mathrm{B} & \mathrm{R} \\
\mathrm{S} & \mathrm{T} \\
\mathrm{T} & \mathrm{U} \\
\mathrm{I} & \mathrm{R} \\
\mathrm{T} & \mathrm{A} \\
\mathrm{U} & \\
\mathrm{I} & \mathrm{V} \\
\mathrm{C} & \mathrm{E} \\
\widetilde{\tilde{A}} & \mathrm{G} \\
\mathrm{O} & \mathrm{E} \\
& \mathrm{T} \\
\mathrm{D} & \mathrm{A} \\
\mathrm{A} & \mathrm{L}\end{array}$ & $\begin{array}{l}\text { P } \\
\text { O } \\
\text { L } \\
\text { U } \\
\text { I } \\
\text { Ç } \\
\text { A } \\
\text { O } \\
\text { D } \\
\text { A } \\
\text { Á } \\
\text { G } \\
\text { U } \\
\text { A }\end{array}$ & $\begin{array}{l}\mathrm{C} \\
\mathrm{O} \\
\mathrm{M} \\
\mathrm{P} \\
\mathrm{A} \\
\mathrm{C} \\
\mathrm{T} \\
\mathrm{A} \\
\mathrm{C} \\
\widetilde{\mathrm{A}} \\
\mathrm{O} \\
\\
\mathrm{D} \\
\mathrm{O} \\
\\
\mathrm{S} \\
\mathrm{O} \\
\mathrm{L} \\
\mathrm{O}\end{array}$ & $\begin{array}{ll}\mathrm{M} & \mathrm{D} \\
\mathrm{O} & \mathrm{A} \\
\mathrm{D} & \\
\mathrm{I} & \mathrm{P} \\
\mathrm{F} & \mathrm{A} \\
\mathrm{I} & \mathrm{I} \\
\mathrm{C} & \mathrm{S} \\
\mathrm{A} & \mathrm{A} \\
\mathrm{C} & \mathrm{G} \\
\widetilde{\mathrm{A}} & \mathrm{E} \\
\mathrm{O} & \mathrm{M}\end{array}$ & $\begin{array}{ll} & \mathrm{N} \\
& \mathrm{E} \\
& \mathrm{C} \\
& \mathrm{E} \\
& \mathrm{S} \\
\mathrm{A} & \mathrm{S} \\
\mathrm{T} & \mathrm{I} \\
\mathrm{E} & \mathrm{D} \\
\mathrm{N} & \mathrm{A} \\
\mathrm{D} & \mathrm{D} \\
\mathrm{I} & \mathrm{E} \\
\mathrm{M} & \mathrm{S} \\
\mathrm{E} & \\
\mathrm{N} & \mathrm{B} \\
\mathrm{T} & \mathrm{A} \\
\mathrm{O} & \mathrm{S} \\
& \mathrm{I} \\
\mathrm{D} & \mathrm{C} \\
\mathrm{A} & \mathrm{A} \\
\mathrm{S} & \mathrm{S}\end{array}$ & $\begin{array}{l}\text { A } \\
\text { C } \\
\text { E } \\
\text { S } \\
\text { S } \\
\text { O } \\
\\
\text { A } \\
\text { O } \\
\text { S } \\
\\
\text { A } \\
\text { T } \\
\text { R } \\
\text { A } \\
\text { T } \\
\text { I } \\
\text { V } \\
\text { O } \\
\text { S }\end{array}$ & $\begin{array}{ll}\mathrm{P} & \\
\mathrm{R} & \\
\mathrm{E} & \\
\mathrm{S} & \\
\mathrm{E} & \\
\mathrm{N} & \\
\mathrm{C} & \\
\mathrm{A} & \\
& \\
\mathrm{D} & \\
\mathrm{E} & \\
& \\
\mathrm{E} & \\
\mathrm{Q} & \\
\mathrm{U} & \mathrm{T} \\
\mathrm{I} & \mathrm{U} \\
\mathrm{P} & \mathrm{R} \\
\mathrm{A} & \mathrm{I} \\
\mathrm{M} & \mathrm{S} \\
\mathrm{E} & \mathrm{T} \\
\mathrm{N} & \mathrm{I} \\
\mathrm{T} & \mathrm{C} \\
\mathrm{O} & \mathrm{O} \\
\mathrm{S} & \mathrm{S}\end{array}$ & $\begin{array}{ll}\text { G } & \\
\text { E } & \\
\text { R } & \\
\text { A } & \\
\text { C } & \\
\widetilde{\widetilde{A}} & \\
\text { O } & \\
& \\
\text { D } & \\
\text { E } & \\
& \\
\text { E } & \text { E } \\
\text { M } & \\
\text { P } & \text { R } \\
\text { R } & \text { E } \\
\text { E } & \text { N } \\
\text { G } & \text { D } \\
\text { O } & \text { A }\end{array}$ & $\begin{array}{lll} & \text { E } \\
& \text { M } \\
& \text { P } \\
& \text { R } \\
& \text { E } \\
& \text { E } \\
\text { A } & \text { N } \\
\text { U } & \text { D } \\
\text { M } & \text { I } \\
\text { E } & \text { M } \\
\text { N } & \text { E } \\
\text { T } & \text { N } \\
\text { O } & \text { T } \\
& \text { O } \\
\text { D } & \text { S } \\
\text { O } & \\
& \text { T } \\
\text { N } & \text { U } \\
\text { Ú } & \text { R } \\
\text { M } & \text { I } \\
\text { E } & \text { S } \\
\text { R } & \text { T } \\
\text { O } & \text { I } \\
& \text { C } \\
\text { D } & \text { O } \\
\text { E } & \text { S }\end{array}$ & $\begin{array}{c}\text { E } \\
\text { S } \\
\text { P } \\
\text { E } \\
\text { C } \\
\text { U } \\
\text { L } \\
\text { A } \\
\text { C } \\
\text { A } \\
\text { O } \\
\\
\text { I } \\
\text { M } \\
\text { O } \\
\text { B } \\
\text { I } \\
\text { L } \\
\text { I } \\
\text { A } \\
\text { R } \\
\text { I } \\
\text { A }\end{array}$ \\
\hline \multirow{2}{*}{ A } & CONCEPÇÃO DO PROJETO & $\square$ & 口 & $\square$ & $\odot$ & $\square$ & ( & $\square$ & 口 & 口 & $\odot$ \\
\hline & PARCELAMENTO DO SOLO & $\odot$ & $\odot$ & $\odot$ & $\odot$ & $\square$ & $\odot$ & $\mathbf{\square}$ & $\mathbf{\square}$ & $\mathbf{\square}$ & $\odot$ \\
\hline \multirow{4}{*}{ B } & DESMATAMENTO & $\mathbf{0}$ & $\mathbf{0}$ & $\odot$ & 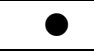 & & & & $\square$ & & \\
\hline & INFRA-ESTRUTURA DE APOIO & ○ & $\odot$ & 0 & - & $\mathbf{\square}$ & $\mathrm{O}$ & 口 & 口 & 口 & $\odot$ \\
\hline & EDIFICAÇÕES & ○ & $\odot$ & 0 & 0 & $\mathbf{\square}$ & $\mathrm{O}$ & $\square$ & $\square$ & 口 & $\odot$ \\
\hline & SINALIZAÇÃO TURÍSTICA & & & & & & & & & & \\
\hline C & REALIZAÇÃO DE EVENTOS & & 0 & & $\bullet$ & $\square$ & & & $\square$ & & \\
\hline
\end{tabular}

Fases: A (Planejamento) B (Construção) C (Operação)

Características do Impacto: Impactos positivos $(\square) \quad$ Impactos negativos: fraco $(\bigcirc)$ moderado $(\odot)$ crítico $(\bullet)$ 
Quadro 6: Síntese dos Impactos no Pólo 11 - Pontão do Lago Sul

\begin{tabular}{|c|c|c|}
\hline AÇÃO & IMPACTOS & $\begin{array}{l}\text { CARACTERÍSTICAS } \\
\text { DOS IMPACTOS }\end{array}$ \\
\hline Concepção do projeto & $\begin{array}{l}\text { - Proposição de medidas } \\
\text { que busquem a manutenção } \\
\text { da qualidade ambiental, } \\
\text { evitando a poluição da água, } \\
\text { erosão do solo e } \\
\text { efeitos. } \\
\text { - Projetos que visam a } \\
\text { alteração significativa da } \\
\text { paisagem, com } \text { muitas } \\
\text { construções e espaços } \\
\text { artificializados. } \\
\text { - Oferta de atrativos que } \\
\text { privilegiam apenas a uma } \\
\text { parte da população do DF, a } \\
\text { de alta renda. } \\
\text { - O projeto busca a melhoria } \\
\text { das condições } \\
\text { urbanização nas áreas onde } \\
\text { se localiza, além da geração } \\
\text { de empregos e de atrair } \\
\text { diversos empreendimentos } \\
\text { para o local. } \\
\end{array}$ & $\begin{array}{c}\text { Positivo } \\
\text { Permanente } \\
\text { Moderado } \\
\text { Negativo } \\
\text { Permanente } \\
\text { Moderado } \\
\text { Negativo } \\
\text { Permanente } \\
\text { Moderado } \\
\\
\text { Positivo } \\
\text { Permanente } \\
\text { Moderado }\end{array}$ \\
\hline Parcelamento do solo & $\begin{array}{l}\text { - A escolha das áreas nas } \\
\text { quais se localizariam os } \\
\text { pólos não leva em conta } \\
\text { aspectos como a distância } \\
\text { até a margem do lago, } \\
\text { havendo ocupação em } \\
\text { Áreas de Preservação } \\
\text { Permanente. } \\
\text { - A localização dos atrativos } \\
\text { beneficia apenas parte da } \\
\text { população. }\end{array}$ & $\begin{array}{l}\text { Negativo } \\
\text { Permanente } \\
\text { Moderado } \\
\\
\text { Negativo } \\
\text { Permanente } \\
\text { Moderado } \\
\end{array}$ \\
\hline Desmatamento & \begin{tabular}{|lrr} 
- Completa & substituição da \\
cobertura vegetal & por \\
asfaltamentos, calçadas & e \\
construções. Isso aumenta o \\
escoamento superficial & e \\
conseqüentemente & a \\
poluição das águas & e \\
erosões. & & \\
- Severa modificação & da \\
paisagem, com & ocupação \\
das margens & sem & a \\
preocupação & com & a \\
distância mínima exigida. &
\end{tabular} & $\begin{array}{l}\text { Negativo } \\
\text { Permanente } \\
\text { Crítico } \\
\\
\\
\text { Negativo } \\
\text { Permanente } \\
\text { Crítico }\end{array}$ \\
\hline $\begin{array}{l}\text { Construção de Infra- } \\
\text { estrutura de Apoio }\end{array}$ & \begin{tabular}{|lll} 
- Completa & substituição da \\
cobertura vegetal & por \\
asfaltamentos, calçadas & e
\end{tabular} & $\begin{array}{c}\text { Negativo } \\
\text { Permanente }\end{array}$ \\
\hline
\end{tabular}




\begin{tabular}{|c|c|c|}
\hline AÇÃO & IMPACTOS & $\begin{array}{l}\text { CARACTERÍSTICAS } \\
\text { DOS IMPACTOS }\end{array}$ \\
\hline & $\begin{array}{l}\text { construções. } \\
\text { - Severa modificação da } \\
\text { paisagem, com ocupação } \\
\text { das margens sem a } \\
\text { preocupação com a } \\
\text { distância mínima exigida. } \\
\text { - A construção de novas } \\
\text { infra-estruturas } \\
\text { empregos e possibilita o o } \\
\text { surgimento de novos } \\
\text { empreendimentos turísticos } \\
\text { na área. }\end{array}$ & $\begin{array}{c}\text { Crítico } \\
\text { Negativo } \\
\text { Permanente } \\
\text { Crítico } \\
\\
\\
\text { Positivo } \\
\text { Permanente } \\
\text { Moderado }\end{array}$ \\
\hline Construções de Edificações & $\begin{array}{l}\text { - Completa substituição da } \\
\text { cobertura vegetal por } \\
\text { asfaltamentos, calçadas e } \\
\text { construções. } \\
\text { - Severa modificação da } \\
\text { paisagem, com ocupação } \\
\text { das margens sem a } \\
\text { preocupação com a a } \\
\text { distância mínima exigida. } \\
\text { - Construções que atendem } \\
\text { às necessidades básicas de } \\
\text { urbanização e presença de } \\
\text { diverso: 44 equipamentos } \\
\text { turísticcu vomo bares, } \\
\text { restaurantes e uma marina. }\end{array}$ & $\begin{array}{l}\text { Negativo } \\
\text { Permanente } \\
\text { Crítico } \\
\text { Negativo } \\
\text { Permanente } \\
\text { Crítico } \\
\\
\\
\text { Positivo } \\
\text { Permanente } \\
\text { Moderado }\end{array}$ \\
\hline Sinalização Turística & $\begin{array}{l}\text { Não foi encontrado nenhum } \\
\text { tipo de sinalização turística. }\end{array}$ & Negativo \\
\hline Realização de eventos & $\begin{array}{l}\text { - Grandes eventos } \\
\text { realizados às margens do } \\
\text { lago podem comprometer } \\
\text { ainda mais as condições da } \\
\text { água e do solo no local. } \\
\text { - Geração de emprego. }\end{array}$ & $\begin{array}{c}\text { Negativo } \\
\text { Temporário } \\
\text { Crítico } \\
\\
\text { Positivo } \\
\text { Temporário }\end{array}$ \\
\hline
\end{tabular}

Fonte: Síntese dos resultados apurados pela Matriz de Interação

No Pontão do Lago Sul, a modificação da paisagem foi ainda mais profunda do que a encontrada no pólo 3 - Complexo do Brasília Palace. Além da substituição da cobertura vegetal por calçadas e estacionamentos, não é possível encontrar exemplares da vegetação nativa no local. As espécies arbóreas plantadas na área em nada lembram o cerrado, assim como as construções e paisagem do Pontão não se adequam à realidade local. A 
entrada e o muro que cerca toda a área, em estilo medieval, não colaboram para a preservação do entorno paisagístico e do estilo modernista, pelo qual Brasília é mundialmente conhecida (figura 9).

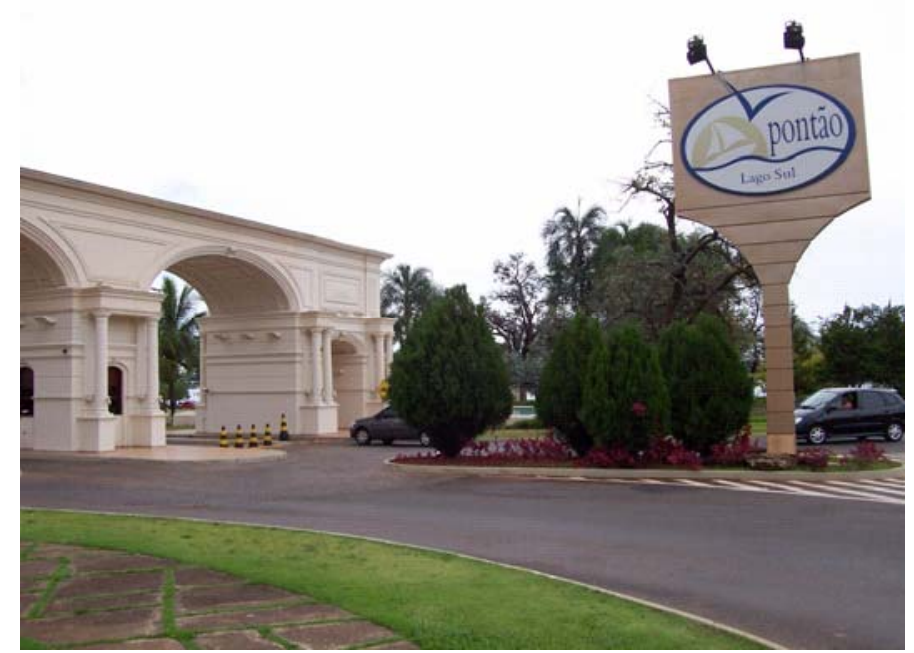

Fonte: LIMA, JOSANA (2007)

Figura 9: Entrada em estilo medieval do Pontão

Toda a área do Pontão do Lago Sul encontra-se muito bem cuidada, a infra-estrutura do local atende todas as necessidades básicas de urbanização como segurança, asfaltamento, iluminação, limpeza pública, banheiros, etc. A manutenção dessas condições é facilitada, já que no local não é permitido nadar, pescar ou fazer piqueniques (figura 10).

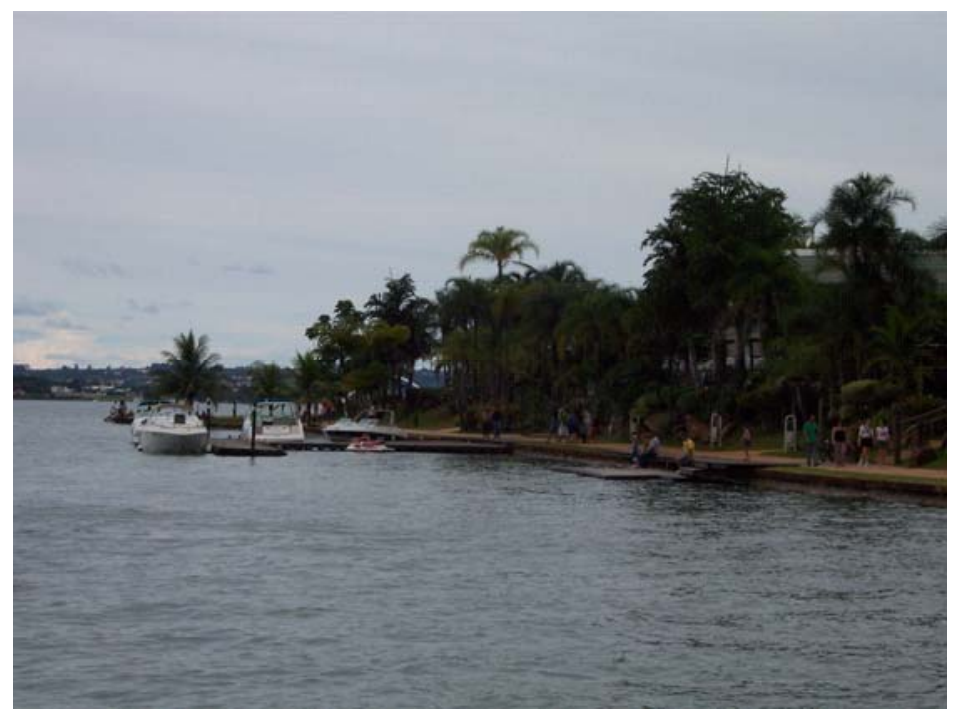

Fonte: LIMA, JOSANA (2007) 
Figura 10: Vegetação na orla do pólo 11

O acesso ao local é comprometido pela falta de sinalização turística, problema encontrado ao longo de toda orla do lago. Quanto ao valor, o acesso aos equipamentos turísticos (bares e restaurantes) dentro do Pontão

é restrito às classes com maior poder aquisitivo uma vez que os preços praticados são bastante elevados. Não há linhas de ônibus que passem pelo local, o que impossibilita o acesso de pessoas de outras cidades. Para portadores de necessidades especiais, o acesso é totalmente garantido.

\section{3 - Análise das imagens de satélite}

Ao se comparar os pólos 3 e 11 do Projeto Orla, percebe-se que a principal diferença refere-se à estrutura de cada pólo. No pólo 3, não há serviços turísticos como lanchonetes, serviços de atendimento ao turista e a estrutura é precária, sem banheiros ou segurança. Não há áreas para descanso e/ou para se refrescar da insolação direta (áreas de sombra), a retirada da vegetação das margens não só agravou o problema ambiental, como comprometeu a paisagem do local.

Quanto à paisagem, um dos principais elementos que compõem um atrativo, o pólo 3 - Complexo do Brasília Palace está arruinado. Além da má impressão, pela falta de vegetação e por ser tomado por calçadas e estacionamentos, a redondeza foi invadida por construções e áreas degradadas (conforme figura 11). Nem a vista para o Lago parece ser um conforto, pela falta de grandes atrativos. 


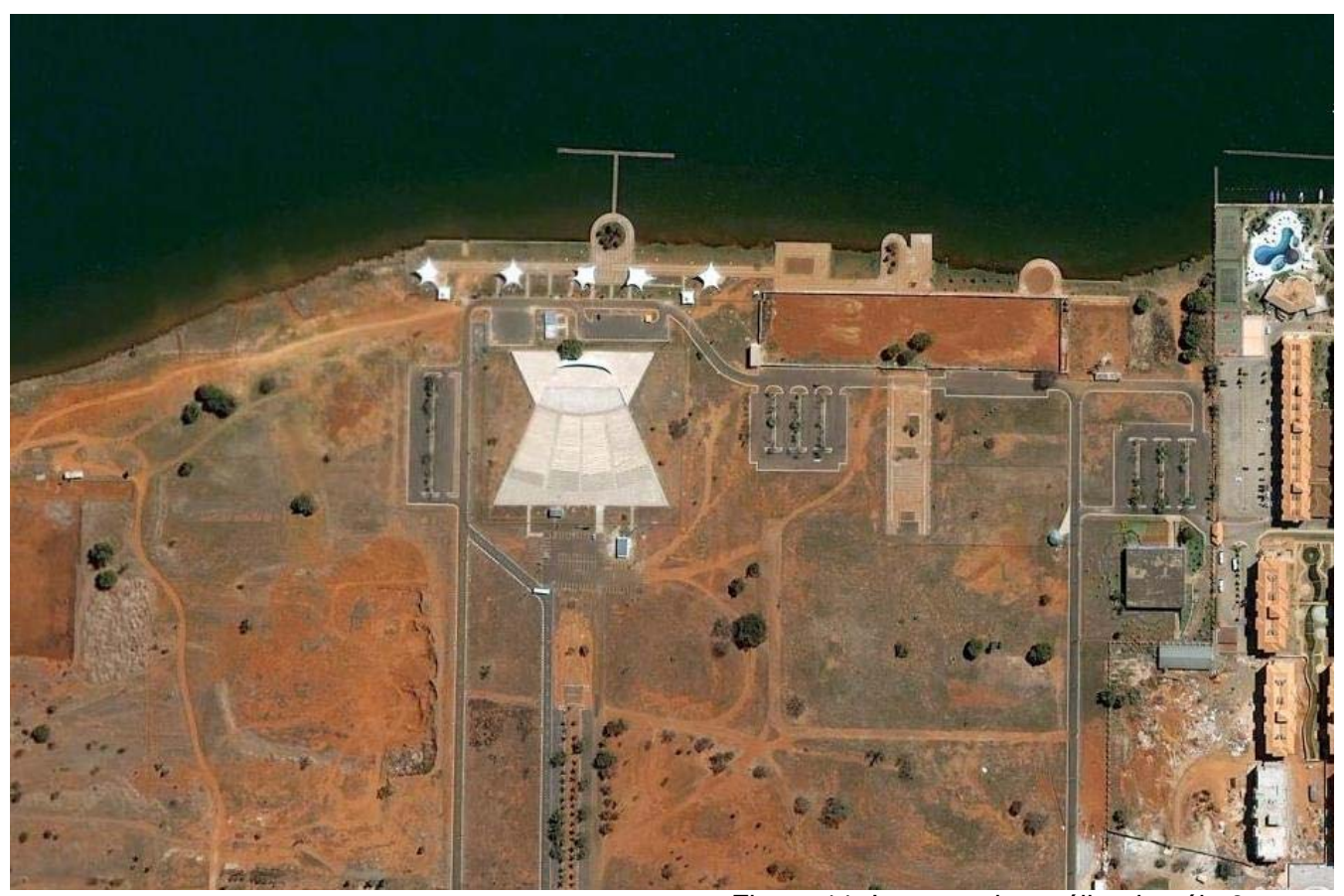

Figura 11: Imagem de satélite do pólo 3.

Escala 1:25000

Fonte: Google Earth

Já no pólo 11 - Pontão do Lago Sul, a situação é inversa. As margens do Lago são gramadas e por toda a orla é possível encontrar vegetação, mesmo que exótica. E as árvores e arbustos, além de melhorar a paisagem, contribuem para proporcionar conforto aos visitantes (vide figura 12). Apesar de não possuir Centro de Atendimento ao Turista, o Pontão do Lago Sul conta com outros serviços turísticos que cumprem seu papel com eficiência. 


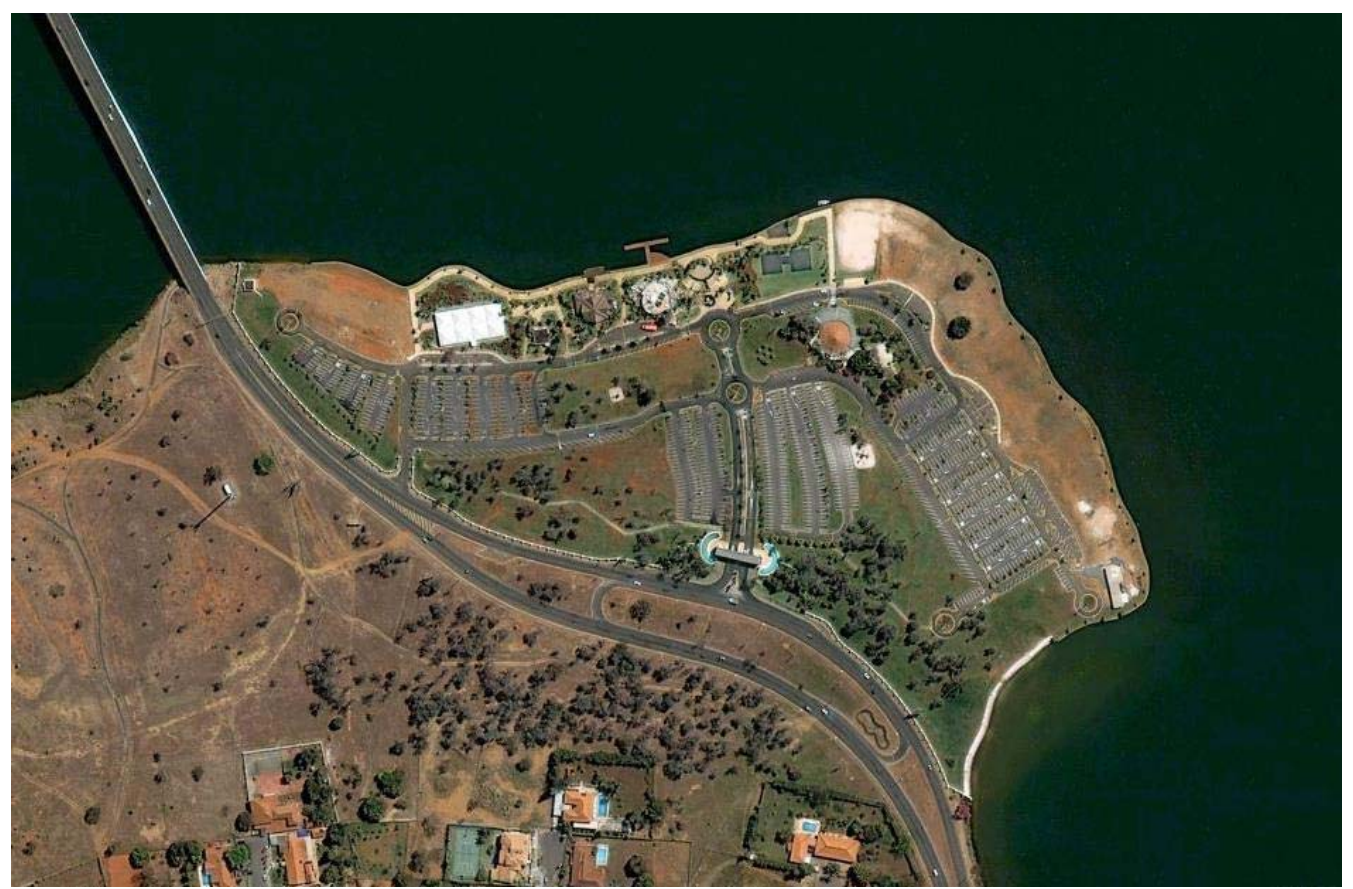

Figura 12: Imagem de satélite do pólo 11.

Escala 1:25000

Fonte: Google Earth

A paisagem do Pontão também é mais privilegiada do que a do pólo

3. Além da vegetação que percorre toda a orla do Lago, ornamentando-a, a vista para o Lago Paranoá tem diversos atrativos como a Ponte JK, a Ponte Costa e Silva, os shoppings e clubes da outra margem, etc. A falta de espaços vazios e abandonados ao redor do pólo 11 também contribui para a melhoria da paisagem no local. 


\section{6 - CONCLUSÃo}

O Projeto Orla foi elaborado, em meados da década de 90, com o objetivo de revitalizar as margens de Lago Paranoá e resgatá-las à população em geral. A proposta apresentava uma série de diretrizes a serem seguidas durante a ocupação das áreas destinadas aos pólos. Entre elas destaca-se:

- Preservação de áreas representativas da vegetação nativa de cerrado, através de sua incorporação aos projetos de intervenções futuras;

- Manutenção da orla no lago livre e desobstruída, para acesso e uso público, com exceção dos terrenos que, hoje, já tenham, legalmente, acesso privativo a água;

- Manutenção da predominância de espaços livres sobre os espaços construídos;

- Proteção das nascentes, cursos d'água e do próprio lago nos termos da legislação vigente, assim como de suas matas ciliares, com a proibição de construções nas faixas de proteção determinadas pela legislação;

- Proibição de quaisquer formas de ocupação e uso que possam causar degradação irreversível ao meio ambiente. ${ }^{5}$

Assim, o Projeto Orla vinha atender a uma demanda da população de Brasília por opções de lazer de fácil acesso. Contudo, depois de passados mais de 10 anos da proposta original do Projeto Orla, pouco foi feito e dos 2 pólos que se encontram consolidados apenas o Pontão do Lago Sul está em bom estado de conservação. Isto devido principalmente à ação da iniciativa privada, pois o Pontão é conhecido pelos famosos e badalados bares e restaurantes.

Já o Pólo 3 não atraiu tanto as ações dos empresários do setor turístico e está em estado de abandono. É possível que esta situação mude,

5 Texto retirado da proposta inicial do Projeto Orla, não publicado. 
à medida que os empreendimentos imobiliários em construção no local se consolidem. Daí, provavelmente, um novo conflito surgirá entre os moradores e os freqüentadores do pólo, já que o padrão de vida e os objetivos com relação ao lago são diferentes.

Apesar das diretrizes e dos cuidados que o projeto previa, as ações às margens do Lago Paranoá não foram tão cautelosas como mostrou a avaliação dos impactos apresentada no capítulo anterior. Foram detectados efeitos negativos à qualidade ambiental tanto no pólo 3 quanto no pólo 11 . A situação torna-se ainda mais crítica uma vez que tais efeitos são de difícil recuperação. É o caso da substituição da cobertura vegetal, presente nos dois pólos analisados.

Quanto aos aspectos sócios culturais e econômicos, é importante ressaltar que as áreas estudadas ainda encontram-se inacessíveis para boa parte da população do Distrito Federal. Seja por problemas relacionados aos meios de transporte (que não chegam aos locais) seja por questões de renda (os atrativos são destinados às pessoas de alto poder aquisitivo), nem todos podem aproveitar as margens do Lago Paranoá.

Desta forma, ao se analisar o Projeto Orla à luz do Desenvolvimento Sustentável e buscando contemplar, nesta análise, os princípios que atendam as três esferas principais da sustentabilidade, a saber: ambiental, sóciocultural e econômica, percebe-se que o planejamento, por si só, não garante que um empreendimento seja verdadeiramente sustentável.

O planejamento do Projeto Orla previa a manutenção da qualidade ambiental, integração das diversas classes sociais do DF, além de geração de renda e emprego, tudo isso através da instalação dos pólos do projeto. 
Contudo, não se prevê modos de avaliação e/ou monitoramento da instalação destes pólos.

$\mathrm{Na}$ verdade, o poder público se exime de responsabilidades e transfere a execução do projeto para a iniciativa privada através da estratégia de concessão dos serviços:

A execução da proposta exigirá uma perfeita integração e sintonia entre os setores público e privado, encarregando-se o primeiro a concepção geral do projeto, sua coordenação e a facilitação da infraestrutura geral necessária à sua implantação. Caberá ao setor privado assumir os investimentos exigidos para a execução dos pólos propostos, em troca dos benefícios resultantes de sua exploração. ${ }^{6}$

Esse foi um dos principais fatores que comprometeram o sucesso do Projeto Orla: a dependência de investimentos da iniciativa privada. Soma-se a isso a falta de infra-estrutura em muitas áreas destinadas aos pólos do Projeto Orla. Ou seja, o poder público não cumpriu sua parte no acordo, dificultando a ação do setor privado.

A esta realidade, conclui-se que apesar o Projeto Orla sugerir planos de ação que garantam a implementação e continuidade do empreendimento, verifica-se que faltaram ações coordenadas por parte dos órgãos e entidades envolvidos na implantação e manutenção do projeto. Para que esta integração se torne possível e permanente é necessário que os órgãos e entidades envolvidos definam formas de atuação, de tal modo que cada decisão corresponda ao resultado de avaliações e posicionamentos oriundos das diferentes áreas.

Para uma futura atuação, tendo este projeto como base, é necessário que haja uma revisão e adequação as condições atuais em que se encontram as margens do lago. Faz-se necessário, também que diversos 
aspectos de infra-estrutura física sejam contemplados nos Planos Diretores, adequando-os às modificações necessárias que atendam os objetivos propostos para a orla do Lago.

Assim, ações tão complexas como as previstas pelo Projeto Orla exigem um planejamento que seja devidamente cumprido ao longo de sua implementação e constantemente avaliado. Deve considerar, principalmente, o meio e a comunidade em que está inserido além de buscar garantir o desenvolvimento sustentável da atividade.

6 Texto retirado da proposta inicial do Projeto Orla, não publicado. 


\section{7 - REFERÊNCIAS BIBLIOGRÁFICAS:}

BARRETO, Margarita. "Planejamento e organização em turismo". 9ed. Campinas, SP: Papirus, 2003.

BNB - Banco do Nordeste do Brasil. "Manual de impactos ambientais: orientações básicas sobre aspectos ambientais de atividades produtivas". Fortaleza: Banco do Nordeste, 1999.

CARVALHO, Eliani Alves. "Ordenamento Territorial, Sustentabilidade e Exclusão: Viajando pelo lago Paranoá". 1998. Dissertação (Mestrado em Arquitetura e Urbanismo)-Faculdade de Arquitetura e Urbanismo; UNB, Brasília, 1998.

CAVACO, Carminda. "Turismo rural e desenvolvimento local". In: RODRIGUES, Adyr (org). Turismo e Geografia: reflexões teóricas e enfoques regionais. $3^{\mathrm{a}}$ ed. São Paulo: Editora Hucitec, 2001.

CMMAD - Comissão Mundial sobre Meio Ambiente e Desenvolvimento."Nosso Futuro Comum". 2ed. Rio de Janeiro: FGV, 1991.

DNER (DNIT). Manual para Ordenamento do Uso do Solo nas Faixas de Domínio e Lindeiras das Rodovias Federais. Rio de Janeiro, 1996. (Ministério dos Transportes).

EMBRATUR - Instituto Brasileiro de Turismo. "Manual de Municipalização do Turismo". 2ed. Brasília, 2001.

FARIA, Doris Santos \& CARNEIRO, Kátia Saraiva. "Sustentabilidade ecológica no turismo". Brasília: Editora Universidade de Brasília, 2001.

FERRETI, Eliane Regina. "Turismo e meio ambiente". São Paulo: Roca.2002. 
FURLAN, Sueli Ângelo. "Unidade de Conservação Insular: considerações sobre a dinâmica insular, planos de manejo e turismo ambiental". In: LEMOS, A.I.G.de (Org.). "Turismo: impactos socioambientais". 2ed. São Paulo:Hucitec,1999.

GLOBE'90 Conference. Tourism Stream and Action Comittee. "An action strategy for sustainable tourism and development". In: EMBRATUR - Instituto Brasileiro de Turismo. "Manual de Municipalização do Turismo". 2ed. Brasília, 2001.

IBAMA - Instituto Brasileiro do Meio Ambiente e dos Recursos Naturais Renováveis. Avaliação de Impacto Ambiental: agentes sociais, procedimentos e ferramentas. Brasília, 1995.

MARGULIS, Sergio. "Meio ambiente: Aspectos técnicos e econômicos." Rio de Janeiro, 1990.

MENDONÇA, Rita. "Turismo ou meio ambiente: uma falsa oposição?" In:LEMOS, A.I.G.de (Org.). "Turismo: impactos socioambientais". 2ed. São Paulo: Hucitec,1999.

OLIVEIRA, Melissa. "O fenomeno turístico e suas implicações na cidade de Ouro Preto." Disponível em:

http://www.anppas.org.br/encontro/segundo/Papers/GT/GT15/melissa.pdf. Acessado em 24/02/2006.

RUSCHMANN, Doris van de Meene. "Turismo e planejamento sustentável: a proteção do meio ambiente". Campinas, SP: Papirus, 1997.

SWARBROOKE, John. "Turismo sustentável: conceitos e impacto ambiental". Série Turismo, Vol. 1. São Paulo: Aleph, 2000. 